\title{
Benthic Diatom Communities of a Large Mediterranean River under the Influence of a Thermal Effluent
}

\author{
Luis Quevedo ${ }^{*}$, Carles Ibáñez ${ }^{2}$, Nuno Caiola² \\ ${ }^{1}$ Escuela Superior Politécnica de Chimborazo, ESPOCH, Riobamba, Ecuador \\ ${ }^{2}$ IRTA Aquatic Ecosystems, Carretera Poble Nou, Catalonia, Spain \\ Email: ${ }^{\star}$ lquevedo@espoch.edu.ec
}

How to cite this paper: Quevedo, L., Ibáñez, C. and Caiola, N. (2018) Benthic Diatom Communities of a Large Mediterranean River under the Influence of a Thermal Effluent. Open Journal of Ecology, 8, 104-125. https://doi.org/10.4236/oje.2018.82008

Received: January 13, 2018

Accepted: February 24, 2018

Published: February 27, 2018

Copyright $\odot 2018$ by authors and Scientific Research Publishing Inc. This work is licensed under the Creative Commons Attribution International License (CC BY 4.0).

http://creativecommons.org/licenses/by/4.0/

\begin{abstract}
The influence of a thermal discharge caused by the cooling system of a nuclear power station on benthic diatom communities was assessed at the lower Ebro River (in Spain), and the information generated could be useful to understand the effects of increasing temperature on large Mediterranean rivers. Surveys conducted at sites before and after the effluent and collected from natural and artificial substrate were analyzed and, Non-metrical Multidimensional Scaling (NMDS), Similarity Percentage Analysis (SIMPER) and 1-way Analysis of Similarities (ANOSIM) were performed to assess changes in community structure. The relationship between diatom assemblages and environmental variables was assessed with a multivariate distance-based linear regression model (DISTLM) and the model was visualized through a redundancy analysis (dbRDA). NMDS ordination was obtained with a stress of 0.18 and 0.17 for natural and artificial substrates, respectively. ANOSIM showed significant differences between Control and Impacted sites $(\mathrm{p}<0.05)$. Simper analysis showed that the mean dissimilarity between Control and Impacted sites was of $42.22 \%$ for natural substrate and of $39.97 \%$ for artificial substrate. DISTLM selected a set of explanatory variables (dissolved oxygen, $\mathrm{T}^{\circ}$ difference, total phosphorus, $\mathrm{pH}$ and chlorophyll) with a $67.24 \%$ of fitted variation. Diatoms showed sensitivity to thermal changes, even though when these did not exceed $3^{\circ} \mathrm{C}$. The factors that seemed to influence benthic assemblages the most were seasonal variation and the thermal increase caused by the nuclear power station.
\end{abstract}

\section{Keywords}

Diatoms, Ebro River, Thermal Pollution, Nuclear 


\section{Introduction}

Diatoms are unicellular algae with a wide spectrum of responses to seasonal and environmental variation, and with optimum ranges of temperature to grow [1] [2] [3]. Each species has different tolerances and preferences, and some have therefore been used as indicators of environmental changes and conditions [4] [5] [6].

Temperature has a significant role in all biochemical and physiological functions of organisms and influences the morphology, physiology, behavior, growth, reproduction, and distribution of species [7] [8], and it has been noted as a main factor influencing primary production [9]. In fact, the rate of photosynthesis depends directly on temperature because it is an enzyme controlled process [10]. It has been reported that warming generally increases the primary production [8].

The importance of temperature in rivers has been widely recognized [9] [11] [12], and the effects of its alteration on aquatic species cover a wide spectrum of direct and indirect effects that range from minor importance to lethal effects [13]. Changes in community structure as response to thermal disturbances have been detected even with a temperature alteration of a few degrees [14] and depend on the preference and tolerance of species to different temperatures as well as on the level of heating.

To generate thermal power, nuclear power stations use nuclear fission to heat water and drive steam turbines that then produce electricity; but this process requires large volumes of water for its cooling system in order to remove the waste heat produced. The increase in river water temperature caused by these thermal discharges has been shown to alter biological and ecological components of aquatic ecosystems [11] [15] [16], but the effects are variable, and depend on the levels and quantity of heated discharge and on the biological features of the environment [17] [18]. Depending on the design and the operating units of the power plants, water temperature in effluent sites can increase by as much as $8^{\circ} \mathrm{C}$ [19]. However, in Europe, legislation requires that the temperature downstream of the effluent should not increase by more than $3^{\circ} \mathrm{C}$ [20].

Many authors have studied the ecological effects of temperature in aquatic environments [1] [13] [15], and several such studies have been based on diatoms [2] [7] [10] [21]. Furthermore, diatoms have been also used as biological proxy to assess the effects of climate change [5] [22] [23] [24]. The impacts of thermal effluents on benthic diatom communities have been studied mostly in estuarine and coastal regions [17] [18] [25] [26] [27], and to a lesser extent in lakes, rivers and streams [28] [29] [30] [31] [32]. However, literature dealing with the effects of thermal pollution on benthic diatom communities of Mediterranean rivers is absent, even though this type of alteration is frequent in the watersheds of the Mediterranean basin.

This study aimed to assess changes in the community structure of benthic diatoms caused by the thermal pollution produced by the cooling system of a nuclear power station (Ascó nuclear power station). This is one of the main anthro- 
pogenic factors exerting pressure on the lower Ebro River and has been subjecting the river to a sustained heating during the last 30 years, therefore providing an excellent opportunity for assessing the long-term effects of water warming on benthic communities. For this purpose, surveys at sites located before and after the effluent were conducted, and to minimize the potential influence of substrate heterogeneity, artificial substrates deployed over the same temperature gradient than natural surfaces were also analyzed.

\section{Materials and Methods}

\subsection{Study Area}

The Ebro River, located in the NE of the Iberian Peninsula (Figure 1(a)) has a

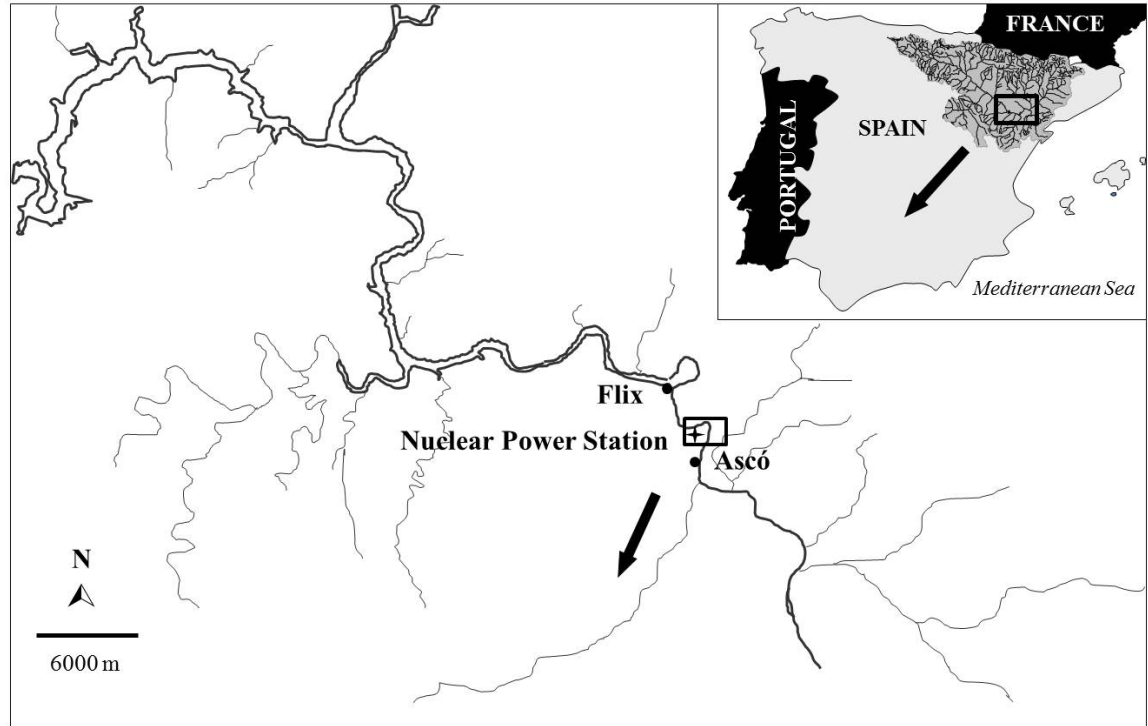

(a)

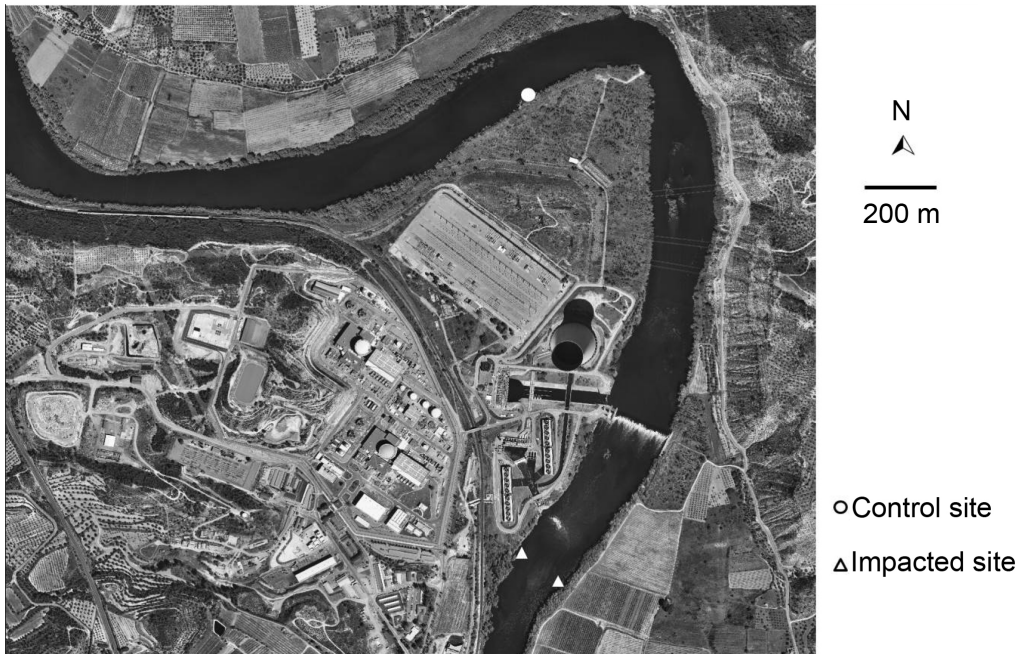

(b)

Figure 1. (a) Map of the lower Ebro River showing the study area; (b) Location of sampling sites. 
length of $928 \mathrm{~km}$; its basin has a surface of $85,534 \mathrm{~km}^{2}$ being one of the most important tributaries to the Mediterranean Sea. Over 180 dams regulate the river flow and the lower part is regulated by two large reservoirs (Mequinensa with a capacity of $1534 \mathrm{hm}^{3}$ and Riba-roja with a capacity of $207 \mathrm{hm}^{3}$ ) built in 1964 and 1969 , respectively for hydropower purposes. The last downstream dam is located at Flix, a small reservoir with a capacity of $11.4 \mathrm{hm}^{3}$.

The Ascó nuclear power station is located at the right margin of the lower Ebro River, $10 \mathrm{~km}$ downstream the Flix dam, between Ascó and Flix towns, and at about $110 \mathrm{~km}$ from the river delta (Figure 1(b)). It was built in 1984 and has two reactors with a gross electrical power output of about 2050 MWe and a thermal reactor power of about $5900 \mathrm{MWt}$. (data available at http://www.anav.es). The power station has granted a concession of $72.3 \mathrm{~m}^{3} / \mathrm{s}$ of the Ebro's flow for its cooling system, and a weir has been built to collect the river water to the condensers. After its use the water is returned to the river with an average thermal increase of $3^{\circ} \mathrm{C}[33]$.

The study area has a total length of $2 \mathrm{~km}$ that comprise $1 \mathrm{~km}$ before and after the nuclear power station $\left(41^{\circ} 12^{\prime} 0^{\prime \prime} \mathrm{N}, 0^{\circ} 34^{\prime} 10^{\prime \prime} \mathrm{E}\right)$.

\subsection{Diatom Sampling and Preparation}

In order to compare benthic community features of a site unimpacted by the heated effluent with those under its influence, three sampling sites were selected: a control site (C), located upstream the nuclear power station, and two impacted sites (I1 and I2) covering the thermal plume, located downstream of the effluent outlet, on the right and left river margins, respectively (Figure 1(b)).

Three sampling campaigns were conducted in August, October and December of 2013. In every occasion, three replicates were collected at each site from both natural substrata (pebbles) and artificial substrata (fired clay bricks placed with a colonization period of 6 weeks). During the summer campaign the artificial substrates placed on site I1 were not recovered due to vandalism.

For every sampling site and occasion, physicochemical data were recorded. A YSI 556 multi-parameter probe was used to measure dissolved oxygen $(\mathrm{mg} / \mathrm{l})$, oxygen saturation (\%), $\mathrm{pH}$, salinity (ppt) and conductivity $(\mathrm{mS} / \mathrm{cm})$; current velocity at $60 \%$ of total water depth was recorded with a Braystoke BFM 001 current meter; total dissolved nitrogen (TDN), total nitrogen (TN), soluble reactive phosphorus (SRP), total phosphorus (TP) were measured according to Koroleff (1977, 1983) [34] [35]; and the total chlorophyll concentration was calculated using the colorimetric method [36]. In each sampling site, water temperature $\left({ }^{\circ} \mathrm{C}\right)$ was monitored at intervals of 30 minutes during all the study period with a TCtemp1000 data logger Madgetech.

Benthic diatom samples were collected according to the recommendations of Kelly et al. (1998) [37]. The suspension was fixed in $4 \%$ formaldehyde solution. At the laboratory, benthic samples were oxidized with $\mathrm{H}_{2} \mathrm{O}_{2} 30 \% \mathrm{v} / \mathrm{v}$ for several hours in order to remove the organic matter. $\mathrm{HCl} 37 \% \mathrm{v} / \mathrm{v}$ was added to evapo- 
rate the carbonates from the samples, as described in Renberg (1990) [38]. Clean valves were permanently mounted with $\mathrm{Naphrax}^{\odot}$ (refractive index 1.74). The permanent slides were examined using a LEICA DMI 3000 B light microscope equipped with differential interference contrast (DIC) with a 100 times oil immersion objective $(\mathrm{n} . \mathrm{a}=1.40)$.

Identification of diatoms was done to species level mainly following Krammer and Lange-Bertalot (1986-1991) [39] but other taxonomic and floristic works were also used when needed. A minimum of 400 valves were counted each time.

\subsection{Data Analysis}

Water temperature values recorded over the study period were analyzed to identify variations and trends, the difference of temperature between control and impacted sites was calculated (Diff_T) and the temperature variability at each site was represented by the standard deviation values (TempSD).

Differences in values of environmental variables between sites were tested with analysis of variance (ANOVA) with Tukey post hoc test performed using software SPSS 19 (SPSS Inc., Chicago, IL, USA).

Diatom abundance is presented as relative percentages and it was square-root transformed in order to reduce the effect of highly variable population densities on ordination scores. All environmental variables that expressed concentration were logarithmically transformed before analysis to avoid skewed distributions.

Descriptive community parameters were calculated: Richness (S), Shannon-Wiener's diversity index $\left(\mathrm{H}^{\prime}\right) \mathrm{H}^{\prime}=-\mathrm{SUM}\left(\mathrm{Pi}^{\star} \log _{\mathrm{e}}(\mathrm{Pi})\right)$, and Pielou's evenness index $\left(\mathrm{J}^{\prime}\right) \mathrm{J}^{\prime}$ $=\mathrm{H} / \log (\mathrm{S})$.

Sites were ordered in relation to their species composition using Non-metric Multidimensional Scaling (NMDS) and significant differences were identified using 1-way Analysis of Similarities test (ANOSIM) [40], that hypothesizes for differences between groups of samples (defined a priori) through randomization methods on a resemblance matrix; ANOSIM provides an $R$ statistic value that reflects the amount of dissimilarity associated with each group, $R$ values close to one indicate very different composition, whereas values near to zero indicate little difference. Then, in order to identify resemblances between sample groups and to identify taxa that contributed to dissimilarity among sites, a Similarity Percentage Analysis (SIMPER) was performed.

Finally, relationship between diatom assemblages and environmental variables was assessed with a multivariate distanced-based linear regression model (DISTLM) [41] and a set of explanatory variables was identified. The model was visualized through a distance-based redundancy analysis (dbRDA) performed using PRIMER V6 software [42] with the add-on package PERMANOVA+ [43].

\section{Results}

\subsection{Environmental Characteristics}

The average values for physicochemical parameters measured at each sampling 
site are shown in Table 1. Water temperature showed constantly higher values at impacted sites as consequence of the water heating produced by the cooling system of the nuclear power station (Figure 2), and was significantly different between control and impacted sites (ANOVA $\mathrm{p}=0.008)(\mathrm{C} \neq \mathrm{I} 1, \mathrm{C} \neq \mathrm{I} 2, \mathrm{I} 1=\mathrm{I} 2)$. The mean values recorded over the study period were $20.54^{\circ} \mathrm{C}$ (C), $23.04^{\circ} \mathrm{C}$ (I1) and $22.98^{\circ} \mathrm{C}$ (I2); while the mean difference of temperature recorded between $\mathrm{C}$ and I1 was $2.39^{\circ} \mathrm{C}$ and $2.33^{\circ} \mathrm{C}$ between $\mathrm{C}$ and I2. Water velocity showed mean values of $0.26 \mathrm{~m} / \mathrm{s}$ at control site, and $0.13 \mathrm{~m} / \mathrm{s}$ and $0.11 \mathrm{~m} / \mathrm{s}$ at Iland $\mathrm{I} 2$ respectively; significant differences between control and impacted sites were found $($ ANOVA $\mathrm{p}=0.000)(\mathrm{C} \neq \mathrm{I} 1, \mathrm{C} \neq \mathrm{I} 2, \mathrm{I} 1=\mathrm{I} 2)$. The other measured environmental variables (dissolved oxygen, $\mathrm{pH}$, conductivity, soluble reactive phosphorus,

Table 1. Values of physicochemical parameters measured at each sampling site. $(\mathrm{T}=$ temperature, Diff. $\mathrm{T}=$ temperature difference, $\mathrm{Temp} \mathrm{SD}=$ temperature variability, $\mathrm{DO}=$ dissolved oxygen, Cond $=$ conductivity, $\mathrm{SPR}=$ soluble reactive phosphate, $\mathrm{TP}=$ total phosphorus, $\mathrm{TDN}=$ total dissolved nitrogen, $\mathrm{TN}=$ total nitrogen, $\mathrm{Chl} \mathrm{a}=$ chlorophyll $\mathrm{a}$ ).

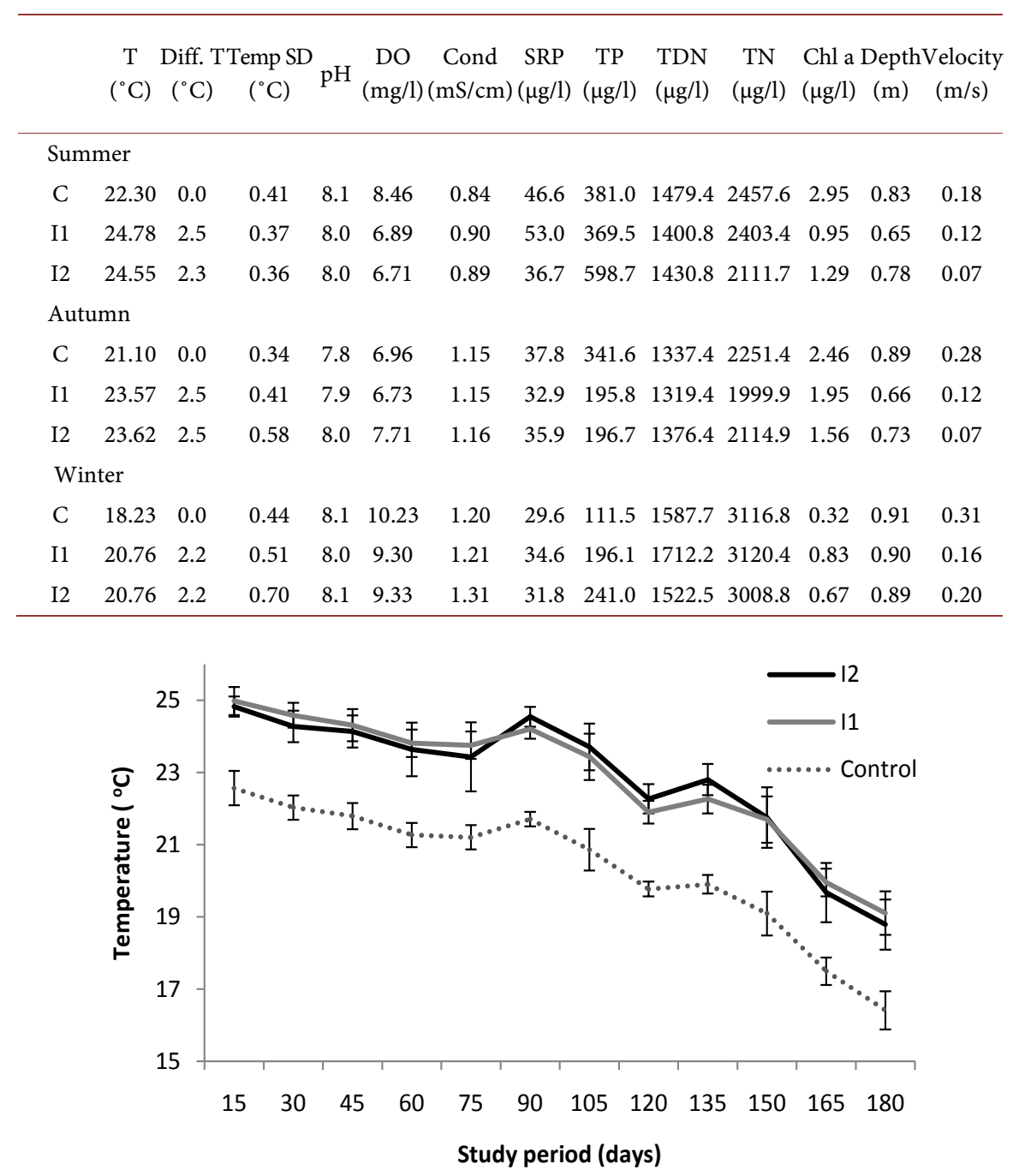

Figure 2. Water temperature recorded over the study period at control (C) and impacted (I1, I2) sites. 
total phosphorus, total dissolved nitrogen, total nitrogen and depth) only showed minor variation and did not present significant differences between sites (ANOVA $\mathrm{p}>0.05$ ). Dissolved oxygen at control site showed highest values than impacted sites in winter $(10.23 \mathrm{mg} / \mathrm{l})$ and in summer $(8.46 \mathrm{mg} / \mathrm{l})$ but in autumn I2 showed the highest value $(7.71 \mathrm{mg} / \mathrm{l})$; $\mathrm{pH}$ showed variation from 7.8 to 8.1 ; conductivity varied from $0.84 \mathrm{mS} / \mathrm{cm}$ in summer (C) to $1.31 \mathrm{mS} / \mathrm{cm}$ in winter (I2); soluble reactive phosphorus showed a minimum of $29.6 \mu \mathrm{g} / \mathrm{l}$ (C, winter) and a maximum of $53 \mu \mathrm{g} / \mathrm{l}$ (I1, summer); total phosphorus ranged from 111.5 $\mu \mathrm{g} / \mathrm{l}$ (C, winter) to $598 \mu \mathrm{g} / \mathrm{l}$ (I2, summer); total dissolved nitrogen varied from $1319.4 \mu \mathrm{g} / \mathrm{l}$ (I1, autumn) to $1712.2 \mu \mathrm{g} / \mathrm{l}$ (I1, winter); total nitrogen showed a minimum of $1999.9 \mu \mathrm{g} / \mathrm{l}$ (I1, autumn) and a maximum of $3120.4 \mu \mathrm{g} / \mathrm{l}$ (I1, winter); and the mean depth values recorded were $0.74 \mathrm{~m} \mathrm{(C),} 0.74 \mathrm{~m}$ (I1) and 0.80 $\mathrm{m}$ (I2).

\subsection{Diatom Assemblages}

During the study period a total of 85 species in natural substrate and 78 species in artificial substrate were found and are listed with their taxon authors and relative abundances in Table A1. Seasonal changes were observed in the diatom community along the study period. In natural substrate assemblages, Amphora pediculus and Nitzschia inconspicua were the dominant species, sharing this dominance with Navicula capitatoradiata in summer, with Amphora copulata in autumn, and with Reimeria uniseriata in winter. Artificial substrate assemblages were dominated in summer by Nitzschia inconspicua, N. palea and Cocconeis placentula var. lineata; in autumn by Amphora pediculus, Cocconeis placentula var. euglypta and Nitzschia inconspicua; and in winter by Amphora pediculus, Cocconeis placentula var. lineata and C. placentula var. trilineata.

Concerning diatom diversity (Table A2), there were no significant differences (ANOVA p > 0.05) between control and impacted sites. However, when mean annual values were analyzed, slightly higher values of species richness and diversity indices were found at impacted sites (Table A3).

The NMDS ordination (Figure 3 ) displays the spatial distribution of the control and impacted sites and the stress obtained was 0.18 and 0.17 for natural and artificial substrates, respectively. For both types of substrate, the assemblage composition was analyzed with ANOSIM and showed significant differences between $\mathrm{C}$ and I1, and between C and I2; but not between I1 and I2 (Table 2).

The Simper analysis (Table A3) for natural substrate assemblages showed that the mean dissimilarity between control and impacted sites was $42.22 \%$ and $A m$ phora pediculus, Nitzschia inconspicua and Navicula capitatoradiata were the species with highest percentage of contribution to dissimilarity between groups. While for artificial substrate, the mean dissimilarly was $39.97 \%$ and the species with the highest contribution were Amphora pediculus, Nitzschia inconspicua and Rhoicosphenia abbreviata.

The dbRDA analysis performed for natural substrate (Figure 4), revealed that 
Table 2. Values of R statistic and significance level of differences between C, I1 and I2 groups, obtained by ANOSIM test for diatom communities of natural and artificial substrate.

\begin{tabular}{cccc}
\hline Groups & R Statistic & Significance & \\
\hline \multicolumn{3}{c}{ Natural Substrate } \\
C, I1 & 0.196 & 0.010 & $*$ \\
C, I2 & 0.299 & 0.005 & $*$ \\
I1, I2 & 0.083 & 0.11 & \\
\hline \multicolumn{2}{c}{ Artificial Substrate } & & $*$ \\
C, I1 & 0.442 & 0.0003 & \\
C, I2 & 0.323 & 0.017 & \\
I1, I2 & 0.213 & 0.05 & \\
\hline
\end{tabular}

Significance: ${ }^{*} \mathrm{p} \leq 0.05 ;{ }^{* *} \mathrm{p} \leq 0.01 ;{ }^{* * *} \mathrm{p} \leq 0.001$.

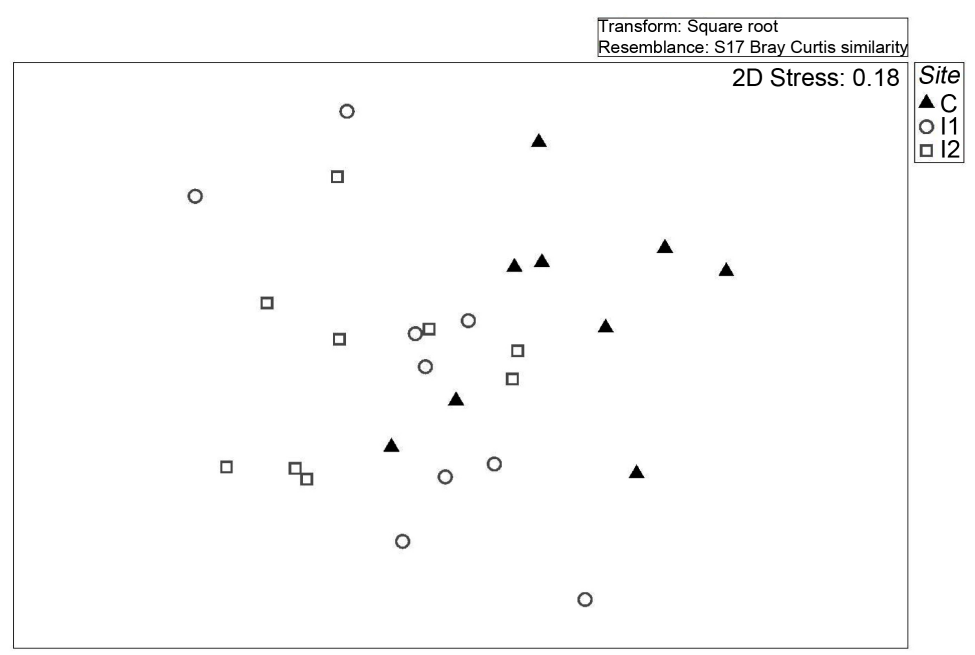

(a)

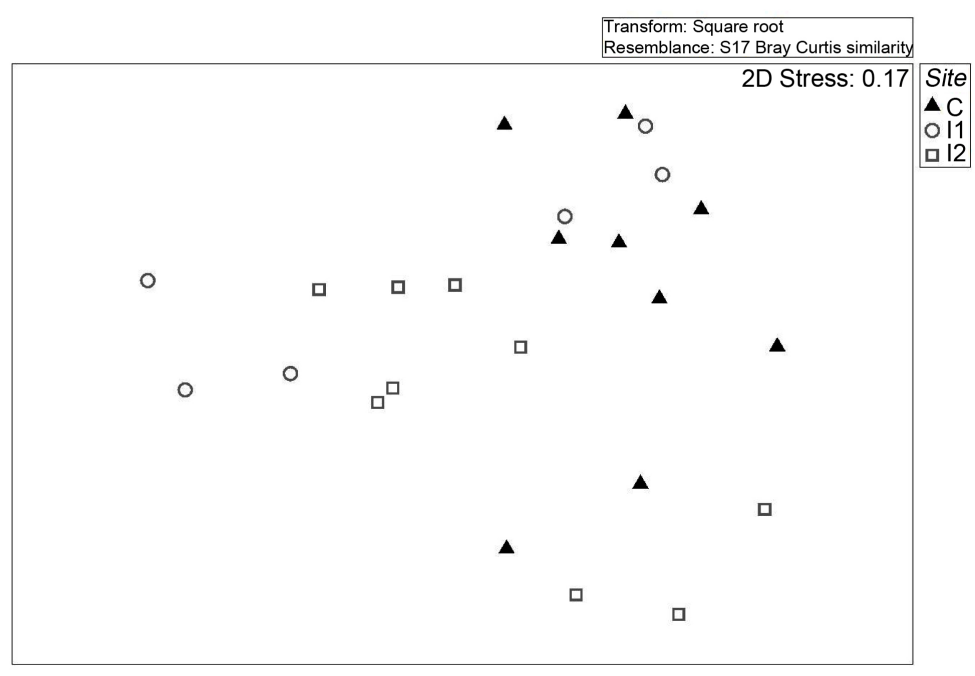

(b)

Figure 3. Two dimensional NMDS plots based on Bray-Curtis similarities of square-root transformed diatom abundance data. (a) Natural substrate ordination; (b) Artificial substrate ordination. 


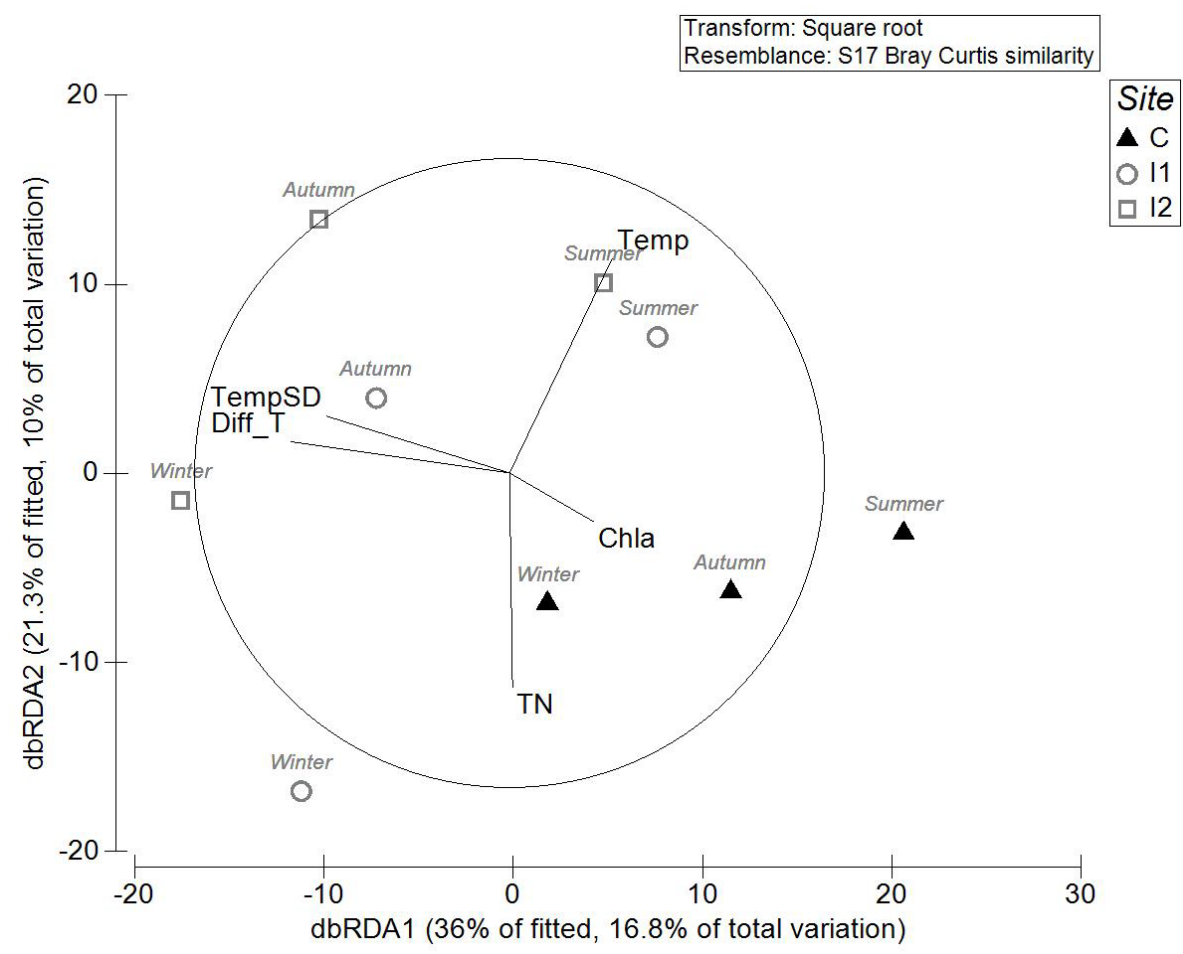

(a)

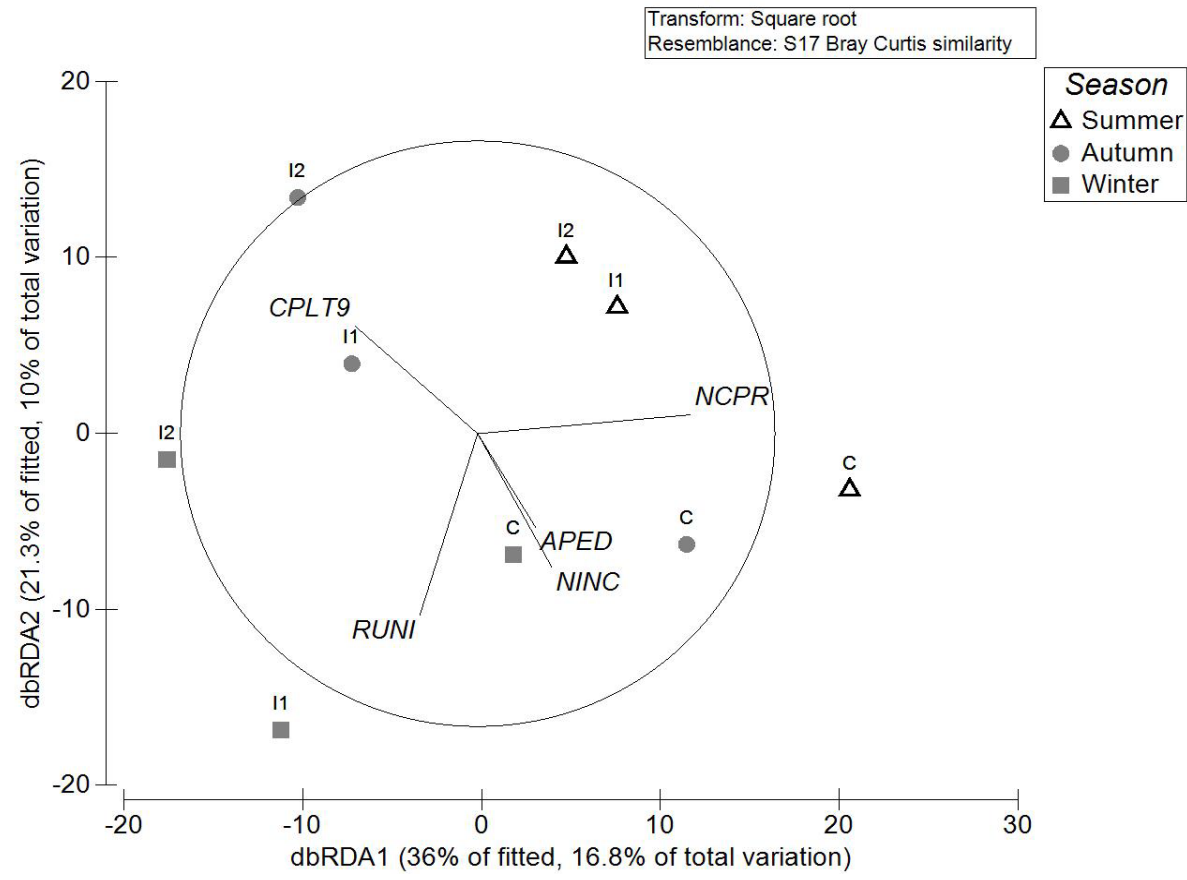

(b)

Figure 4. Distance-based redundancy analysis (dbRDA) ordination of natural substrate data: (a) Samples displayed by site and season and vectors showing correlation between explaining variables and dbRDA axes; (b) Samples displayed by season and site and vectors showing correlation between the five species with highest contribution to the dissimilarity between control and impacted sites and dbRDA axes. (NCPR = Navicula capitatoradiata, APED = Amphora pediculus, NINC = Nitzschia inconspicua, RUNI = Reimeria uniseriata CPLT9 = Cocconeis placentula var. trilineata). 
the set of variables selected by the DISTLM $\left(\mathrm{T}^{\circ}\right.$, total nitrogen, $\mathrm{T}^{\circ}$ difference, chlorophyll and $\mathrm{T}^{\circ}$ variability) explained $57.27 \%$ of fitted variation and $26.81 \%$ of total variation in the two first axes; while the dbRDA performed on artificial substrate (Figure 5), revealed that the set of variables selected by the DISTLM (dissolved oxygen, $\mathrm{T}^{\circ}$ difference, total phosphorus, $\mathrm{pH}$ and chlorophyll) explained $67.24 \%$ of fitted variation and $39.55 \%$ of total variation in the first two axes. Water velocity was not selected by the DISTLM as part of the explanatory variables set.

The first axis of the dbRDA plots of both natural (Figure 4) and artificial (Figure 5) substrates distinguished samples from control and impacted sites and in both cases the axis was strongly correlated with the difference in water temperature caused by Ascó nuclear power station. The second dbRDA axis, also of both natural (Figure 4) and artificial (Figure 5) substrates, basically distinguished autumn and winter samples from those of summer and was strongly correlated with a gradient of temperature and nutrient levels (total nitrogen for natural substrate and total phosphorus for artificial substrate) associated with the seasonal variation in the fluvial system. The five species with the highest contribution to the dissimilarity between control and impacted sites are represented in the dbRDA plots (Figure 4 and Figure 5).

\section{Discussion}

The presence of the nuclear power station has been producing a sustained increase of water temperature occurring over the last 30 years at the Ebro River.

The values recorded for environmental variables and the distribution of samples indicated a seasonal variation explained by the natural fluctuation of conductivity, $\mathrm{pH}$, dissolved oxygen and nutrients related with changes in temperature and flow as consequence of the annual cycle and hydrodynamics of the river. However, this process has been altered by a thermal increase consistently greater than $2^{\circ} \mathrm{C}$ in the river, and the results obtained in this study show the existence of two different diatom assemblages inhabiting in sites before and after the nuclear power station.

Most of environmental variables measured shared the same values or showed a little variation between control and impacted sites; therefore, the differences detected in diatoms assemblages could be mostly attributable to the warming effect, either by its direct influence or by its interaction with other functional processes. The sensitivity of diatoms to changes in water temperature is widely recognized [44] [45] [46]. Increases in temperature have complex effects, for instance affecting the diffusion rates of chemicals and reducing the amount of oxygen that water may maintain; these changes in the environmental conditions will very likely affect the reproductive rates and metabolism of the algae [47] [48] and therefore lead to changes in community structure.

Diatom assemblages were significantly different between control and impacted sites; these differences were mainly due to variation in community composition expressed as species abundances rather than species presence or absence. 


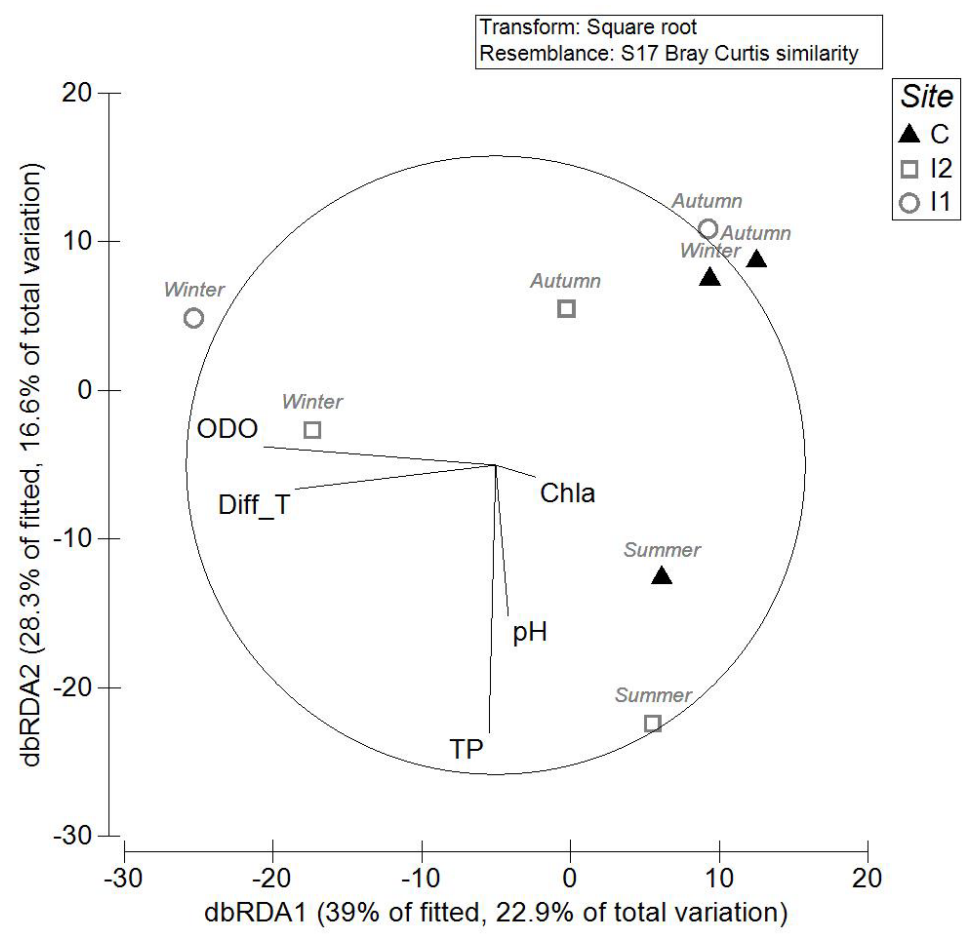

(a)

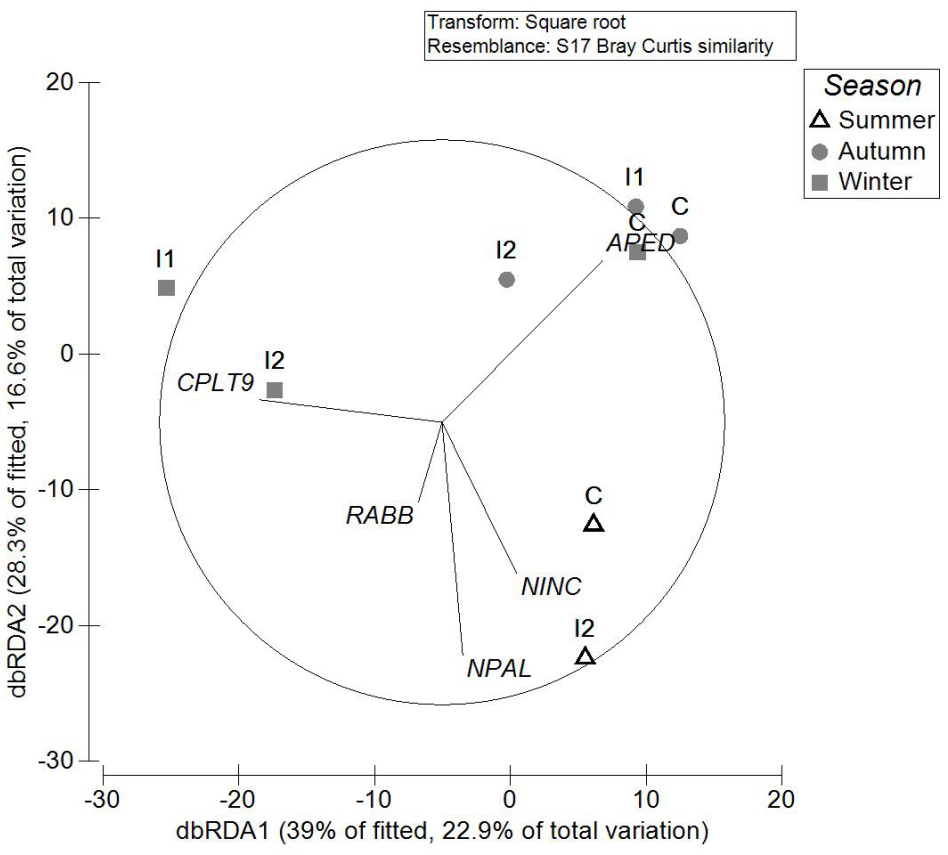

(b)

Figure 5. Distance-based Redundancy Analysis (dbRDA) ordination of artificial substrate data: (a) Samples displayed by site and season and vectors showing correlation between explaining variables and dbRDA axes; (b) Samples displayed by season and site and vectors showing correlation between the five species with highest contribution to the dissimilarity between control and impacted sites and dbRDA axes. (APED = Amphora pediculus, NINC $=$ Nitzschia inconspicua, $\mathrm{NPAL}=$ Nitzschia palea, $\mathrm{RABB}=$ Rhoicosphenia abbreviata, CPLT9 = Cocconeis placentula var. trilineata). 
These changes in abundance could be related to specific physiological responses of species to their optimal temperature ranges, but may also be related to shifts as consequence of interspecies interactions as competition or due to the influence of other environmental variables. Our data do not allow to attribute the observed changes in community structure solely to the temperature alteration, but evidence that warming is a determinant factor influencing or enhancing other factors on the structure of communities.

In this study, the species pool did not show significant variation; we found slightly higher values in species richness and diversity indices at the impacted sites. For algae, it has been documented that diversity increases from $0^{\circ} \mathrm{C}$ to $25^{\circ} \mathrm{C}$ and starts to decrease at temperatures above $30^{\circ} \mathrm{C}$ [3] [8] [9], though changes in community structure are usually more evident at temperatures from $25^{\circ} \mathrm{C}$ to $30^{\circ} \mathrm{C}$ rather than $<25^{\circ} \mathrm{C}$ [7]. During the study period, temperature never exceeded $25^{\circ} \mathrm{C}$ and changes detected in species composition were minor and due to species with low relative abundances $(<5 \%)$. Similar results were reported in a study including benthic epilithic communities under thermal influence, where Hillebrand et al. (2010) [26] found that elevating the water temperature increased temporal beta-diversity and decreased compositional stability of communities; and instead of changes in species richness, it was observed a change of proportion of species from the same pool. Changes in diatom community structure as consequence of thermal alteration were documented by Squires et al. (1979) [31] who found that the algal flora was significantly affected at the section immediately below the discharge point of a power station; and Vinson and Rushforth (1989) [32] noted that diversity and species richness increased with temperature and maximum values were reached between $25^{\circ} \mathrm{C}$ and $30^{\circ} \mathrm{C}$, beyond this temperature species diversity decreased; parallel results were also found by Patrick (1969) [2].

The colonization on artificial substrate seemed to be dominated by opportunistic diatom species with fast growth rates such as Amphora pediculus, Nitzschia inconspicua and Rhoicosphenia abbreviata, which can quickly form large blooms and compete with other algal species with slower growth rates, as has been previously highlighted by Snoeijs and Prentice (1989) [27]. These species also showed high abundance on natural substrate and in both cases (natural and artificial substrate), dominance was shared with Cocconeis spp., which did not show a clear preference between control and impacted sites. These results are opposite to those found by Stevenson et al. (1996) [48] who detected a shift to dominance of Cocconeis in warmer waters but this discrepancy could be explained, perhaps, by the results of De Nicola (1996) [7], who noted that Cocconeis tended to be more abundant in waters above $25^{\circ} \mathrm{C}$ and as mentioned before, we did not record values exceeding that temperature. Interestingly, although there are some community differences between natural and artificial substrate, both provided essentially the same picture of thermal influence. This agrees with some previous works where again it was found that benthic diatom communities tend to be much more affected by the environmental conditions than by sub- 
strate type [49] [50] [51].

Diatom communities proved to be sensitive to water warming even though this alteration did not exceed $3^{\circ} \mathrm{C}$. The factors that seemed to have most effect on the benthic assemblages inhabiting the area influenced by the nuclear power station, were the seasonal variation and thermal alteration caused by the heated effluent.

Nowadays, aquatic ecosystems are threatened as consequence of greater water demands and climate change, and to ensure their adequate management, it is evident the need to better understand the response of biota to thermal alterations. This is especially important for Mediterranean ecosystems, since this region of the world is going to be among the most impacted ones by climate change, and in particular by global warming [52]. By using the thermal gradient in the nuclear power station plume it is possible to cover part of the range of future scenarios of temperature and therefore, our results could be of interest to predict changes in benthic communities under global warming scenarios. However, it is important to note that this work focused on a local species pool along a period of time when the regional species pool did not change, and it has been pointed out that global warming will lead to turnover also in the regional species pools by actions as emigration or adaptation of species from other regions [53]; thus, changes in local species could also be influenced by changes on regional scales if the temperature increase affect larger areas over longer periods [26].

We think that the information generated here will contribute to a better understanding of the effects of increasing temperature on the benthic diatom communities of Mediterranean rivers and hence will provide useful baseline data for predicting the effects of global warming under future projected scenarios.

\section{Acknowledgements}

This study was funded by the Secretaría de Educación Superior, Ciencia, Tecnología e Innovación (SENESCYT) of Ecuador, which provided a doctoral research fellowship to the first author. Special thanks are given to David Mateu and Lluís Jornet (IRTA) for their invaluable help in the sampling campaigns.

\section{References}

[1] Hawkes, H.A. (1969) Ecological Changes of Applied Significance Induced by the Discharge of Heated Waters. In: Parker, F.L. and Krenkel, P., Eds., Engineering Aspects of Thermal Pollution, Vanderbilt University Press, Nashville Tennessee, $15-57$.

[2] Patrick, R. (1969) Some Effects of Temperature on Freshwater Algae. In: Krenkel, P.A. and Parker, F., Eds., Biological Aspects of Thermal Pollution, Vanderbilt University Press, Nashville, 161-198.

[3] Patrick, R. (1971) Effects of Increasing Light and Temperature on the Structure of Diatom Communities. Limnology and Oceanography, 16, 405-421. https://doi.org/10.4319/lo.1971.16.2.0405

[4] Chessman, B., Growns, I., Currey, J. and Plunkett-Cole, N. (1999) Predicting Diatom Communities at the Genus Level for the Rapid Biological Assessment of Riv- 
ers. Freshwater Biology, 41, 317-331.

https://doi.org/10.1046/j.1365-2427.1999.00433.x

[5] McCormick, P.V. and Cairns, J.R.J. (1994) Algae as Indicators of Environmental Change. Journal of Applied Phycology, 6, 509-526.

https://doi.org/10.1007/BF02182405

[6] Whitton, B.A. and Kelly, M.G. (1995) Use of Algae and Other Plants for Monitoring Rivers. Australian Journal of Ecology, 20, 45-56. https://doi.org/10.1111/j.1442-9993.1995.tb00521.x

[7] De Nicola, D.M. (1996) Periphyton Responses to Temperature at Different Ecological Levels. In: Stevenson, R.J., Bothwell, M.L. and Lowe, R.L., Eds., Algal Ecology in Freshwater Benthic Ecosystems, Academic Press, San Diego, 149-181.

[8] Kishi, D., Murakami, M., Nakano, S. and Maekawa, K. (2005) Water Temperature Determines Strength of Top-Down Control in a Stream Food Web. Freshwater Biology, 50, 1315-1322. https://doi.org/10.1111/j.1365-2427.2005.01404.x

[9] Dallas, H. (2008) Water Temperature and Riverine Ecosystems: An Overview of Knowledge and Approaches for Assessing Biotic Responses, with Special Reference to South Africa. Water $S A, 34,393-404$.

[10] Raven, J.A. and Geider, R.J. (1988) Temperature and Algal Growth. New Phytologist, 110, 441-461. https://doi.org/10.1111/j.1469-8137.1988.tb00282.x

[11] Caissie, D. (2006) The Thermal Regime of Rivers: A Review. Freshwater Biology, 51, 1389-1406. https://doi.org/10.1111/j.1365-2427.2006.01597.x

[12] Ward, J.V. (1985) Thermal Characteristics of Running Waters. In: Davies, B.R. and Walmsley, R.D., Eds., Perspectives in Southern Hemisphere Limnology, Springer, Berlin, 31-46. https://doi.org/10.1007/978-94-009-5522-6_3

[13] Verones, F., Hanafiah, M.M., Pfister, S., Huijbregts, M.A.J., Pelletier, G.J. and Koehler, A. (2010) Characterization Factors for Thermal Pollution in Freshwater Aquatic Environments. Environmental Science \& Technology, 44, 9364-9369. https://doi.org/10.1021/es102260c

[14] Kaushal, S.S., Likens, G.E., Jaworski, N.A., Pace, M.L., Sides, A.M., Seekell, D., Belt, K.T., Secor, D.H. and Wingate, R.L. (2010) Rising Stream and River Temperatures in the United States. Frontiers in Ecology and the Environment, 8, 461-466. https://doi.org/10.1890/090037

[15] De Vries, P., Tamis, J.E., Murk, A.J. and Smit, M.G.D. (2008) Development and Application of a Species Sensitivity Distribution for Temperature-Induced Mortality in the Aquatic Environment. Environmental Toxicology and Chemistry, 27, 2591-2598. https://doi.org/10.1897/08-056.1

[16] Langford, T. (1990) Ecological Effects of Thermal Discharges. Springer Science \& Business Media, London.

[17] Lardicci, C., Rossi, F. and Maltagliati, F. (1999) Detection of Thermal Pollution: Variability of Benthic Communities at Two Different Spatial Scales in an Area Influenced by a Coastal Power Station. Marine Pollution Bulletin, 38, 296-303. https://doi.org/10.1016/S0025-326X(98)00149-0

[18] Teixeira, T.P., Neves, L.M. and Araújo, F.G. (2010) Thermal Impact of a Nuclear Power Plant in a Coastal Area in Southeastern Brazil: Effects of Heating and Physical Structure on Benthic Cover and Fish Communities. Hydrobiologia, 684, 161-175. https://doi.org/10.1007/s10750-011-0980-1

[19] Laws, E.A. (1993) Aquatic Pollution: An Introductory Text. 2nd Edition, John Wiley \& Sons, New York. 
[20] European Union (2006) Directive 2006/44/EC of the European Parliament and of the Council of 6 September 2006, on the Quality of Fresh Waters Needing Protection or Improvement in Order to Support Fish Life. Official Journal of the European Communities, L264, 20-31.

[21] Potapova, M.G. and Charles, D.F. (2002) Benthic Diatoms in USA Rivers: Distributions along Spatial and Environmental Gradients. Journal of Biogeography, 29, 167-187. https://doi.org/10.1046/j.1365-2699.2002.00668.x

[22] Perkins, D.M., Reiss, J., Yvon-Durocher, G. and Woodward, G. (2010) Global Change and Food Webs in Running Waters. Hydrobiologia, 657, 181-198. https://doi.org/10.1007/s10750-009-0080-7

[23] Stevenson, R.J. and Sabater, S. (2010) Understanding Effects of Global Change on River Ecosystems: Science to Support Policy in a Changing World. Hydrobiologia, 657, 3-18. https://doi.org/10.1007/s10750-010-0392-7

[24] Wrona, F.J., Prowse, T.D., Reist, J.D., Hobbie, J.E., Lévesque, L.M.J. and Vincent, W.F. (2006) Climate Change Effects on Aquatic Biota, Ecosystem Structure and Function. AMBIO: A Journal of the Human Environment, 35, 359-369. https://doi.org/10.1579/0044-7447(2006)35[359:CCEOAB]2.0.CO;2

[25] Hein, M.K. and Koppen, J.D. (1979) Effects of Thermally Elevated Discharges on the Structure and Composition of Estuarine Periphyton Diatom Assemblages. Estuarine and Coastal Marine Science, 9, 385-401. https://doi.org/10.1016/0302-3524(79)90013-6

[26] Hillebrand, H., Soininen, J. and Snoeijs, P. (2010) Warming Leads to Higher Species Turnover in a Coastal Ecosystem. Global Change Biology, 16, 1181-1193. https://doi.org/10.1111/j.1365-2486.2009.02045.x

[27] Snoeijs, P.J.M. and Prentice, I.C. (1989) Effects of Cooling Water Discharge on the Structure and Dynamics of Epilithic Algal Communities in the Northern Baltic. Hydrobiologia, 184, 99-123. https://doi.org/10.1007/BF00014306

[28] Boylen, C.W. and Brock, T.D. (1973) Effects of Thermal Additions from the Yellowstone Geyser Basins on the Benthic Algae of the Firehole River. Ecology, 54, 1282-1291. https://doi.org/10.2307/1934190

[29] Hickman, M. and Klarer, D.M. (1975) The Effect of the Discharge of Thermal Effluent from a Power Station on the Primary Productivity of an Epiphytic Algal Community. British Phycological Journal, 10, 81-91. https://doi.org/10.1080/00071617500650081

[30] Lamberti, G. and Resh, V. (1985) Distribution of Benthic Algae and Macroinvertebrates along a Thermal Stream Gradient. Hydrobiologia, 128, 13-21. https://doi.org/10.1007/BF00008935

[31] Squires, L., Rushforth, S. and Brotherson, J. (1979) Algal Response to a Thermal Effluent: Study of a Power Station on the Provo River, Utah, USA. Hydrobiologia, 63, 17-32. https://doi.org/10.1007/BF00021013

[32] Vinson, D. and Rushforth, S. (1989) Diatom Species Composition along a Thermal Gradient in the Portneuf River, Idaho, USA. Hydrobiologia, 185, 41-54. https://doi.org/10.1007/BF00006066

[33] Prats, J., Val, R., Armengol, J. and Dolz, J. (2010) Temporal Variability in the Thermal Regime of the Lower Ebro River (Spain) and Alteration due to Anthropogenic Factors. Journal of Hydrology, 387, 105-118. https://doi.org/10.1016/j.jhydrol.2010.04.002

[34] Koroleff, F. (1977) Simultaneous Persulfate Oxidation of Phosphorus and Nitrogen Compounds in Water. In: Grasshoff, K., Ed., Report of the Baltic Intercalibration 
Worshop, Annex Interim Commission for the Protection of the Environment of the Baltic Sea, 52-53.

[35] Koroleff, F. (1983) Determination of Phosphorus. In: Grasshoff, K., Ehrhardt, M. and Kremling, K., Eds., Methods of Seawater Analysis, Verlag Chemie, 125-132.

[36] Jeffrey, S. and Humphrey, G. (1975) New Spectrophotometric Equations for Determining Chlorophylls a, b, c1 and c2 in Higher Plants, Algae and Natural Phytoplankton. Biochem Physiol Pflanzen, 167, 191-194. https://doi.org/10.1016/S0015-3796(17)30778-3

[37] Kelly, M., Cazaubon, A., Coring, E., Dell'uomo, A., Ector, L., Goldsmith, B., Guasch, H., Hürlimann, J., Jarlman, A. and Kawecka, B. (1998) Recommendations for the Routine Sampling of Diatoms for Water Quality Assessments in Europe. Journal of Applied Phycology, 10, 215-224. https://doi.org/10.1023/A:1008033201227

[38] Renberg, I. (1990) A Procedure for Preparing Large Sets of Diatom Slides from Sediment Cores. Journal of Paleolimnology, 4, 87-90. https://doi.org/10.1007/BF00208301

[39] Krammer, K., Lange-Bertalot, H., Bate, N., Podzorski, A. and Bukowska, J. (1986-1991) Bacillariophyceae 1Teil: Naviculaceae (1986); 2 Teil: Bacillariaceae, Epithemiaceae, Surirellaceae, (1988); 3 Teil: Centrales, Fragilariaceae, Eunotiaceae, (1991a); 4 Teil: Achnanthaceae, Kritische Ergäänzungen zu Navicula (Lineolatae) und Gomphonema Gesamtliteraturverzeichnis, (1991b). In: Ettl, H., Gerloff, J., Heying, H. and Mollenhauer, D., Eds., Süßwasserflora von Mitteleuropa, Gustav Fischer Verlag, Stuttgart, 1-876.

[40] Anderson, M.J. and Walsh, D.C. (2013) PERMANOVA, ANOSIM, and the Mantel test in the Face of Heterogeneous Dispersions: What Null Hypothesis Are You Testing? Ecological Monographs, 83, 557-574. https://doi.org/10.1890/12-2010.1

[41] McArdle, B.H. and Anderson, M.J. (2001) Fitting Multivariate Models to Community Data: A Comment on Distance-Based Redundancy Analysis. Ecology, 82, 290-297. https://doi.org/10.1890/0012-9658(2001)082[0290:FMMTCD]2.0.CO;2

[42] Clarke, K.R. and Gorley, R. (2006) PRIMER v6: User Manual/Tutorial. Primer-E, Plymouth.

[43] Anderson, M.J., Gorley, R.N. and Clarke, K.R. (2008) PERMANOVA+ for PRIMER: Guide to Software and Statistical Methods. PRIMER-E, Plymouth.

[44] Moore, J.W. (1977) Seasonal Succession of Algae in a Eutrophic Stream in Southern England. Hydrobiologia, 53, 181-192. https://doi.org/10.1007/BF00029297

[45] Moore, J.W. (1977) Seasonal Succession of Algae in Rivers. II. Examples from Highland Water, a Small Woodland Stream. Hidrobiologia, 80, 160-171.

[46] Stevenson, R.J. and Pan, Y. (1999) Assessing Environmental Conditions in Rivers and Streams with Diatoms. In: Stoermer, E.F. and Smol, J.P., Eds., The Diatoms. Applications for the Environmental and Earth Sciences, Cambridge University Press, New York, 1-4. https://doi.org/10.1017/CBO9780511613005.003

[47] Smol, J.P. and Stoermer, E.F. (2010) The Diatoms: Applications for the Environmental and Earth Sciences. Cambridge University Press, Cambridge. https://doi.org/10.1017/CBO9780511763175

[48] Stevenson, R.J., Bothwell, M.L., Lowe, R.L. and Thorp, J.H. (1996) Algal Ecology: Freshwater Benthic Ecosystem. Academic Press, Cambridge.

[49] Lane, C.M., Taffs, K.H. and Corfield, J.L. (2003) A Comparison of Diatom Community Structure on Natural and Artificial Substrata. Hydrobiologia, 493, 65-79. https://doi.org/10.1023/A:1025498732371 
[50] Rovira, L., Trobajo, R. and Ibanez, C. (2009) Periphytic Diatom Community in a Mediterranean Salt Wedge Estuary: The Ebro Estuary (NE Iberian Peninsula). Acta Botanica Croatica, 68, 285-300.

[51] Rovira, L., Trobajo, R., Leira, M. and Ibáñez, C. (2012) The Effects of Hydrological Dynamics on Benthic Diatom Community Structure in a Highly Stratified Estuary: The Case of the Ebro Estuary (Catalonia, Spain). Estuarine, Coastal and Shelf Science, 101, 1-14. https://doi.org/10.1016/j.ecss.2011.12.033

[52] IPCC (2013) Climate Change 2013: The Physical Science Basis. Summary for Policymakers. Contribution of Working Group 1 to the Fifth Assessment Report of the Intergovernmental Panel on Climate Change. Cambridge University Press, Cambridge.

[53] Parmesan, C. and Yohe, G. (2003) A Globally Coherent Fingerprint of Climate Change Impacts across Natural Systems. Nature, 421, 37-42.

https://doi.org/10.1038/nature01286 


\section{Appendix}

Table A1. List of diatom taxa found and their relative abundances (\%) over the study period at control (C), and impacted sites (I1 and I2).

\begin{tabular}{|c|c|c|c|c|c|c|c|c|c|c|c|c|c|c|c|c|c|c|}
\hline & \multirow{3}{*}{ Taxa } & \multicolumn{9}{|c|}{ Natural Substrate } & \multicolumn{8}{|c|}{ Artificial Substrate } \\
\hline & & \multicolumn{3}{|c|}{ Summer } & \multicolumn{3}{|c|}{ Autumn } & \multicolumn{3}{|c|}{ Winter } & \multicolumn{2}{|c|}{ Summer } & \multicolumn{3}{|c|}{ Autumn } & \multicolumn{3}{|c|}{ Winter } \\
\hline & & $\mathrm{C}$ & I1 & I2 & $\mathrm{C}$ & I1 & I2 & $\mathrm{C}$ & I1 & I2 & $\mathrm{C}$ & I2 & $\mathrm{C}$ & I1 & I2 & $\mathrm{C}$ & I1 & I2 \\
\hline ACON & Achnanthes conspicua A. Mayer & 0.4 & 0.1 & 0.6 & 0.6 & 0.1 & 0.0 & 0.0 & 0.0 & 0.0 & 0.1 & 0.4 & 0.1 & 0.0 & 0.0 & 0.2 & 0.6 & 0.3 \\
\hline ADMI & $\begin{array}{l}\text { Achnanthidium minutissimum (Kützing) } \\
\text { Czarnecki }\end{array}$ & 3.4 & 0.8 & 1.8 & 1.5 & 0.5 & 0.0 & 0.7 & 0.3 & 3.0 & 2.1 & 4.3 & 7.4 & 1.5 & 1.5 & 1.5 & 0.0 & 1.3 \\
\hline ANMN & Actinocyclus normanii (Gregory) Hustedt & 0.1 & 0.1 & 0.0 & 0.5 & 0.3 & 1.1 & 0.0 & 0.0 & 0.3 & 0.0 & 0.0 & 0.1 & 0.0 & 0.0 & 0.0 & 0.0 & 0.0 \\
\hline ACYB & Amphora cymbamphora Cholnoky & 0.0 & 0.2 & 0.0 & 0.0 & 0.6 & 0.0 & 0.0 & 0.7 & 0.0 & 0.0 & 0.0 & 0.0 & 0.2 & 0.0 & 0.0 & 0.0 & 0.1 \\
\hline $\mathrm{ACOE}$ & $\begin{array}{l}\text { Amphora copulata (Kützing) } \\
\text { Schoeman \& Archibald }\end{array}$ & 2.5 & 6.7 & 4.8 & 13.1 & 10.1 & 4.5 & 2.4 & 4.2 & 3.8 & 2.3 & 0.3 & 7.2 & 11.4 & 5.4 & 5.5 & 8.7 & 4.3 \\
\hline AMID & Amphora indistincta Levkov & 0.5 & 5.5 & 5.5 & 5.2 & 1.9 & 5.3 & 2.3 & 3.7 & 5.8 & 1.0 & 0.1 & 2.1 & 1.0 & 0.4 & 1.5 & 0.5 & 0.1 \\
\hline AOVA & Amphora ovalis (Kützing) Kützing & 0.1 & 0.8 & 0.9 & 1.7 & 0.7 & 0.9 & 0.2 & 0.8 & 0.3 & 0.0 & 0.1 & 0.0 & 0.4 & 0.8 & 0.0 & 5.8 & 0.6 \\
\hline APED & Amphora pediculus (Kützing) Grunow & 25.8 & 22.5 & 18.8 & 23.3 & 10.0 & 5.5 & 26.9 & 21.4 & 26.4 & 8.1 & 2.3 & 28.3 & 38.3 & 8.2 & 34.9 & 1.8 & 6.0 \\
\hline $\mathrm{AAMB}$ & Aulacoseira ambigua (Grunow) Simonsen & 0.0 & 0.5 & 0.5 & 0.0 & 0.0 & 0.7 & 0.4 & 0.3 & 1.2 & 0.0 & 0.1 & 0.0 & 0.0 & 1.2 & 0.0 & 1.4 & 0.8 \\
\hline AUGR & Aulacoseira granulata (Ehrenberg) Simonsen & 0.0 & 0.1 & 0.0 & 0.0 & 0.4 & 0.0 & 0.0 & 0.0 & 0.0 & 0.0 & 0.0 & 0.0 & 0.0 & 0.0 & 0.0 & 0.0 & 0.0 \\
\hline BPAR & Bacillaria paradoxa Gmelin in Linneaeus & 0.1 & 0.0 & 0.0 & 0.0 & 0.0 & 0.2 & 0.0 & 0.3 & 0.6 & 0.0 & 0.0 & 0.0 & 0.0 & 0.1 & 0.0 & 0.6 & 0.2 \\
\hline $\mathrm{CBAC}$ & Caloneis bacillum (Grunow) Cleve & 0.0 & 0.1 & 0.3 & 0.2 & 0.3 & 0.2 & 0.0 & 0.2 & 0.0 & 0.2 & 0.1 & 0.0 & 0.6 & 0.6 & 0.2 & 0.0 & 0.0 \\
\hline CPED & Cocconeis pediculus Ehrenberg & 0.8 & 4.9 & 4.8 & 0.8 & 0.7 & 0.7 & 0.7 & 0.6 & 1.5 & 2.0 & 3.2 & 1.1 & 0.3 & 1.8 & 0.9 & 0.8 & 3.2 \\
\hline CPLE & $\begin{array}{l}\text { Cocconeis placentula Ehrenberg var. } \\
\text { euglypta (Ehrenberg) Grunow }\end{array}$ & 2.5 & 3.0 & 3.6 & 1.6 & 1.7 & 6.9 & 2.8 & 1.6 & 4.8 & 9.4 & 3.3 & 7.4 & 9.4 & 10.7 & 6.4 & 8.0 & 7.5 \\
\hline CPLI & $\begin{array}{l}\text { Cocconeis placentula var. lineata } \\
\text { (Ehrenberg) Van Heurck }\end{array}$ & 3.8 & 5.5 & 3.5 & 2.6 & 4.1 & 7.7 & 2.9 & 3.7 & 7.5 & 8.7 & 4.5 & 6.2 & 3.2 & 5.8 & 8.3 & 9.8 & 13.6 \\
\hline CPLA & $\begin{array}{l}\text { Cocconeis placentula Ehrenberg var. } \\
\text { placentula }\end{array}$ & 2.2 & 2.1 & 2.1 & 0.7 & 0.6 & 2.4 & 1.6 & 1.5 & 4.9 & 7.5 & 1.9 & 1.7 & 1.7 & 2.3 & 5.7 & 5.4 & 8.9 \\
\hline CPLT9 & $\begin{array}{l}\text { Cocconeis placentula var. trilineata } \\
\text { (Peragallo \& Héribaud) Cleve }\end{array}$ & 0.6 & 2.4 & 1.9 & 0.7 & 1.4 & 11.3 & 1.2 & 1.9 & 5.9 & 3.2 & 1.9 & 2.3 & 1.6 & 7.5 & 4.7 & 7.9 & 14.2 \\
\hline CSCU & $\begin{array}{l}\text { Cocconeis scutellum Ehrenberg var. } \\
\text { scutellum }\end{array}$ & 0.0 & 0.0 & 0.0 & 0.0 & 0.0 & 0.0 & 0.0 & 0.0 & 0.2 & 0.0 & 0.0 & 0.0 & 0.0 & 0.0 & 0.0 & 2.1 & 0.5 \\
\hline CAMB & Craticula ambigua (Ehrenberg) D. G. Mann & 0.0 & 0.0 & 0.0 & 0.0 & 0.0 & 0.0 & 0.0 & 0.0 & 0.0 & 0.2 & 0.0 & 0.0 & 0.0 & 0.0 & 0.0 & 0.0 & 0.0 \\
\hline CDUB & Cyclostephanos dubius (Fricke) Round & 0.0 & 0.1 & 0.2 & 0.2 & 0.1 & 0.4 & 0.4 & 0.3 & 0.2 & 0.0 & 0.1 & 0.3 & 0.0 & 0.2 & 0.2 & 1.1 & 0.2 \\
\hline CMEN & Cyclotella meneghiniana Kützing & 0.9 & 0.1 & 0.2 & 0.0 & 0.0 & 0.0 & 0.0 & 0.1 & 0.1 & 2.3 & 0.1 & 0.0 & 0.0 & 0.0 & 0.0 & 0.0 & 0.0 \\
\hline COCE & Cyclotella ocellata Pantocsek & 0.0 & 0.0 & 0.0 & 0.0 & 0.1 & 0.2 & 0.6 & 0.6 & 0.4 & 0.1 & 0.0 & 0.0 & 0.0 & 0.5 & 0.2 & 1.4 & 2.7 \\
\hline CAFV & Cymbella affinis Kützing & 0.0 & 0.0 & 0.0 & 0.2 & 0.3 & 0.2 & 0.0 & 0.0 & 0.0 & 0.0 & 0.0 & 0.0 & 0.0 & 0.0 & 0.0 & 0.0 & 0.0 \\
\hline CLAN & Cymbella lanceolata (C. Agardh) Kirchner & 0.0 & 0.0 & 0.0 & 0.0 & 0.0 & 0.0 & 0.0 & 0.0 & 0.0 & 0.0 & 0.0 & 0.0 & 0.0 & 0.1 & 0.0 & 0.0 & 0.0 \\
\hline DCOF & Diadesmis confervacea Kützing & 0.1 & 0.0 & 0.0 & 0.1 & 0.1 & 0.1 & 0.0 & 0.0 & 0.0 & 0.1 & 0.0 & 0.1 & 0.0 & 0.0 & 0.0 & 0.0 & 0.0 \\
\hline DVUL & Diatoma vulgaris Bory & 0.3 & 1.2 & 1.1 & 1.7 & 1.0 & 2.9 & 2.0 & 0.3 & 0.2 & 0.0 & 0.4 & 0.6 & 0.8 & 2.0 & 0.0 & 0.8 & 0.9 \\
\hline DOVA & Diploneis ovalis (Hilse) Cleve & 0.0 & 0.0 & 0.0 & 0.0 & 0.2 & 0.0 & 0.0 & 0.4 & 0.1 & 0.0 & 0.0 & 0.0 & 0.0 & 0.1 & 0.0 & 0.0 & 0.0 \\
\hline EARE & Ellerbeckia arenaria (Moore) Crawford & 0.0 & 0.3 & 0.2 & 0.3 & 0.2 & 0.8 & 0.0 & 1.0 & 1.7 & 0.0 & 0.1 & 0.1 & 0.0 & 0.7 & 0.0 & 0.6 & 0.4 \\
\hline ENMI & $\begin{array}{l}\text { Encyonema minutum (Hilse in Rabenhorst) } \\
\text { D. G. Mann in Round, Crawford \& Mann }\end{array}$ & 0.4 & 0.8 & 1.6 & 0.3 & 0.1 & 0.2 & 0.3 & 0.0 & 0.0 & 0.4 & 1.1 & 0.4 & 0.3 & 0.3 & 0.2 & 0.2 & 0.0 \\
\hline
\end{tabular}




\section{Continued}

\begin{tabular}{|c|c|c|c|c|c|c|c|c|c|c|c|c|c|c|c|c|c|c|}
\hline EPRO & Encyonema prostratum (Berkeley) Kützing & 0.2 & 0.3 & 0.0 & 0.1 & 0.8 & 0.0 & 0.0 & 0.0 & 0.0 & 0.0 & 0.3 & 0.0 & 0.1 & 0.0 & 0.1 & 0.0 & 0.1 \\
\hline EOMI & Eolimna minima (Grunow) Lange-Bertalot & 0.0 & 0.1 & 0.3 & 0.4 & 0.2 & 0.5 & 0.0 & 0.7 & 0.1 & 0.2 & 0.1 & 0.2 & 0.5 & 0.9 & 0.0 & 0.0 & 0.1 \\
\hline ESBM & $\begin{array}{l}\text { Eolimna subminuscula (Manguin) Moser, } \\
\text { Lange-Bertalot \& Metzeltin }\end{array}$ & 0.8 & 0.0 & 0.5 & 1.2 & 0.3 & 0.1 & 0.3 & 1.4 & 0.1 & 0.7 & 0.7 & 0.9 & 1.5 & 0.6 & 0.9 & 0.0 & 0.5 \\
\hline FPYG & $\begin{array}{l}\text { Fallacia pygmaea (Kützing) Stickle \& D. G. } \\
\text { Mann in Round, Crawford \& Mann }\end{array}$ & 0.0 & 0.0 & 0.0 & 0.0 & 0.4 & 0.0 & 0.0 & 0.0 & 0.0 & 0.0 & 0.0 & 0.0 & 0.0 & 0.0 & 0.0 & 0.3 & 0.0 \\
\hline FFAS & $\begin{array}{l}\text { Fragilaria fasciculata (C. Agardh) } \\
\text { Lange-Bertalot }\end{array}$ & 0.3 & 1.5 & 0.7 & 0.7 & 0.9 & 1.4 & 0.6 & 0.6 & 1.0 & 0.5 & 0.4 & 0.5 & 0.1 & 1.1 & 0.2 & 1.2 & 1.6 \\
\hline FVBR & Frustulia vulgaris (Thwaites) De Toni & 0.0 & 0.0 & 0.0 & 0.0 & 0.0 & 0.0 & 0.0 & 0.0 & 0.2 & 0.0 & 0.0 & 0.0 & 0.0 & 0.0 & 0.0 & 0.0 & 0.1 \\
\hline GDEC & $\begin{array}{l}\text { Geissleria decussis (Østrup) } \\
\text { Lange-Bertalot \& Metzeltin }\end{array}$ & 0.0 & 0.0 & 0.1 & 0.0 & 0.0 & 0.0 & 1.0 & 0.2 & 0.0 & 0.1 & 0.1 & 0.0 & 0.0 & 0.0 & 0.0 & 0.0 & 0.0 \\
\hline GMIN & $\begin{array}{l}\text { Gomphonema minutum (C. Agardh) C. } \\
\text { Agardh }\end{array}$ & 1.5 & 2.0 & 2.0 & 1.0 & 1.2 & 3.2 & 1.9 & 0.2 & 0.6 & 0.9 & 7.0 & 3.2 & 0.6 & 1.4 & 0.8 & 2.7 & 2.0 \\
\hline GOLI & $\begin{array}{l}\text { Gomphonema olivaceum (Hornemann) } \\
\text { Brébisson }\end{array}$ & 0.5 & 0.1 & 0.0 & 0.0 & 0.0 & 0.0 & 0.5 & 0.0 & 0.0 & 0.0 & 0.1 & 0.0 & 0.0 & 0.0 & 0.1 & 0.0 & 0.0 \\
\hline GPAR & Gomphonema parvulum (Kützing) Kützing & 4.2 & 0.9 & 1.1 & 0.6 & 0.6 & 0.0 & 0.8 & 0.1 & 0.3 & 0.4 & 5.3 & 0.0 & 0.7 & 0.7 & 0.4 & 0.5 & 0.1 \\
\hline GRHB & Gomphonema rhombicum M. Schmidt & 0.6 & 0.2 & 1.0 & 0.4 & 3.5 & 3.1 & 2.0 & 1.5 & 1.8 & 0.5 & 4.9 & 6.9 & 1.4 & 3.5 & 0.9 & 2.6 & 0.9 \\
\hline GTRU & Gomphonema truncatum Ehrenberg & 0.6 & 0.1 & 0.6 & 0.1 & 0.1 & 0.1 & 0.0 & 0.0 & 0.0 & 0.3 & 0.1 & 0.0 & 0.3 & 0.0 & 0.0 & 0.0 & 0.0 \\
\hline GYAT & Gyrosigma attenuatum (Kützing) Rabenhorst & 0.0 & 1.4 & 0.2 & 0.3 & 0.7 & 1.2 & 0.3 & 1.3 & 0.8 & 0.0 & 0.1 & 0.1 & 0.1 & 0.3 & 0.1 & 4.4 & 0.6 \\
\hline HLMO & Halamphora montana (Krasske) Levkov & 0.0 & 0.0 & 0.0 & 0.0 & 0.0 & 0.0 & 0.0 & 0.0 & 0.0 & 0.0 & 0.0 & 0.0 & 0.0 & 0.1 & 0.0 & 0.0 & 0.0 \\
\hline HVEN & Halamphora veneta (Kützing) Levkov & 0.0 & 0.0 & 0.0 & 0.0 & 0.1 & 0.1 & 0.0 & 0.0 & 0.0 & 0.0 & 0.0 & 0.0 & 0.0 & 0.0 & 0.0 & 0.0 & 0.1 \\
\hline KCLE & $\begin{array}{l}\text { Karayevia clevei (Grunow) } \\
\text { Round \& Bukhtiyarova }\end{array}$ & 0.1 & 0.0 & 0.0 & 0.1 & 0.3 & 0.1 & 0.0 & 5.8 & 0.4 & 0.0 & 0.0 & 0.0 & 0.0 & 0.0 & 0.0 & 0.0 & 0.0 \\
\hline KAPG & $\begin{array}{l}\text { Karayevia ploenensis (Hustedt) Bukhtiyarova } \\
\text { var. gessneri (Hustedt) Bukhtiyarova }\end{array}$ & 0.1 & 0.3 & 0.2 & 0.3 & 0.0 & 0.3 & 0.1 & 0.1 & 0.1 & 0.4 & 0.1 & 0.3 & 0.1 & 0.3 & 0.6 & 0.0 & 0.5 \\
\hline LGOE & Luticola goeppertiana (Bleisch) D. G. Mann & 0.0 & 0.0 & 0.0 & 0.0 & 0.0 & 0.1 & 0.0 & 4.0 & 2.4 & 0.0 & 0.0 & 0.0 & 0.4 & 0.0 & 0.0 & 0.0 & 1.1 \\
\hline MPMI & $\begin{array}{l}\text { Mayamaea permitis (Hustedt) } \\
\text { Bruder \& Medlin }\end{array}$ & 0.1 & 0.5 & 0.0 & 0.2 & 0.0 & 0.1 & 0.2 & 0.2 & 0.0 & 0.0 & 0.0 & 0.0 & 0.0 & 0.0 & 0.0 & 0.0 & 0.0 \\
\hline MVAR & Melosira varians C. Agardh & 0.8 & 3.7 & 0.9 & 5.5 & 2.6 & 3.1 & 3.8 & 0.6 & 1.3 & 2.8 & 1.6 & 0.7 & 0.5 & 2.8 & 0.5 & 3.0 & 2.3 \\
\hline NANT & Navicula antonii Lange-Bertalot & 6.5 & 5.9 & 6.4 & 1.7 & 4.5 & 5.4 & 2.2 & 0.5 & 0.9 & 6.8 & 2.3 & 0.9 & 1.1 & 1.1 & 3.0 & 0.7 & 1.1 \\
\hline NCAP & Navicula capitata Ehrenberg & 0.1 & 0.1 & 0.0 & 0.0 & 0.0 & 0.0 & 0.0 & 0.0 & 0.2 & 0.0 & 0.0 & 0.0 & 0.0 & 0.2 & 0.0 & 0.8 & 0.0 \\
\hline NCPR & Navicula capitatoradiata Germain & 12.4 & 4.9 & 3.8 & 0.7 & 1.6 & 0.2 & 2.5 & 0.0 & 0.3 & 1.7 & 2.1 & 0.3 & 0.7 & 0.6 & 0.1 & 0.8 & 0.7 \\
\hline NCAR & Navicula cari Ehrenberg & 0.0 & 0.2 & 0.0 & 0.0 & 0.8 & 0.1 & 0.4 & 0.4 & 0.0 & 0.0 & 0.0 & 0.1 & 0.9 & 1.2 & 0.0 & 0.0 & 0.0 \\
\hline NCTE & Navicula cryptotenella Lange-Bertalot & 1.4 & 4.4 & 5.5 & 2.0 & 5.6 & 2.4 & 3.1 & 1.9 & 2.4 & 7.2 & 2.7 & 1.6 & 2.1 & 3.5 & 7.7 & 5.3 & 2.3 \\
\hline NGER & Navicula germainii Wallace & 0.0 & 0.0 & 0.0 & 0.0 & 0.0 & 0.1 & 0.4 & 0.0 & 0.0 & 0.0 & 0.1 & 0.0 & 0.0 & 0.0 & 0.0 & 0.0 & 0.0 \\
\hline NGRE & Navicula gregaria Donkin & 0.0 & 0.0 & 0.0 & 0.0 & 0.0 & 0.0 & 0.8 & 0.0 & 2.8 & 0.0 & 0.0 & 0.0 & 0.0 & 0.0 & 0.0 & 0.0 & 1.6 \\
\hline NHEL & Navicula helensis Schulz & 0.0 & 0.0 & 0.2 & 0.0 & 0.2 & 0.0 & 0.0 & 0.0 & 0.0 & 0.0 & 0.0 & 0.0 & 0.2 & 0.1 & 0.0 & 0.0 & 0.2 \\
\hline NINO & Navicula ignota Krasske & 0.4 & 1.3 & 1.1 & 0.0 & 0.5 & 0.0 & 0.3 & 1.3 & 0.1 & 0.7 & 0.1 & 0.0 & 0.6 & 0.0 & 0.2 & 0.0 & 0.1 \\
\hline NLAN & Navicula lanceolata (Agardh) Ehrenberg & 0.0 & 0.0 & 0.0 & 0.0 & 0.0 & 0.1 & 0.3 & 0.1 & 0.0 & 0.0 & 0.0 & 0.0 & 0.0 & 0.0 & 0.0 & 0.0 & 0.0 \\
\hline
\end{tabular}




\section{Continued}

\begin{tabular}{|c|c|c|c|c|c|c|c|c|c|c|c|c|c|c|c|c|c|c|}
\hline NRCS & $\begin{array}{l}\text { Navicula recens (Lange-Bertalot) } \\
\text { Lange-Bertalot }\end{array}$ & 0.0 & 0.0 & 0.0 & 0.0 & 3.7 & 0.0 & 0.9 & 0.1 & 0.0 & 0.0 & 0.0 & 0.0 & 0.0 & 0.0 & 0.0 & 0.0 & 0.0 \\
\hline $\mathrm{NRCH}$ & $\begin{array}{l}\text { Navicula reichardtiana Lange-Bertalot in } \\
\text { Krammer \& Lange-Bertalot }\end{array}$ & 0.0 & 0.0 & 0.0 & 0.0 & 0.0 & 0.0 & 1.0 & 0.0 & 0.0 & 0.7 & 0.0 & 0.0 & 0.0 & 0.0 & 0.0 & 0.0 & 0.0 \\
\hline NTPT & Navicula tripunctata (O. F. Müller) Bory & 0.0 & 0.6 & 1.2 & 1.8 & 3.6 & 5.6 & 0.5 & 2.5 & 0.9 & 0.0 & 0.4 & 0.3 & 1.1 & 2.3 & 0.6 & 3.7 & 0.9 \\
\hline NVEN & Navicula veneta Kützing & 0.0 & 0.0 & 0.3 & 0.0 & 1.5 & 0.0 & 2.8 & 0.5 & 1.2 & 0.0 & 0.2 & 0.0 & 0.1 & 0.5 & 0.3 & 0.8 & 1.2 \\
\hline NAMP & Nitzschia amphibia Grunow & 4.1 & 0.9 & 2.9 & 3.2 & 5.0 & 3.9 & 2.6 & 0.7 & 2.6 & 1.1 & 1.9 & 5.9 & 3.4 & 3.7 & 1.5 & 1.2 & 1.9 \\
\hline NCPL & $\begin{array}{l}\text { Nitzschia capitellata Hustedt in A. } \\
\text { Schmidt \& al. }\end{array}$ & 0.3 & 0.0 & 0.1 & 0.0 & 0.0 & 0.0 & 0.1 & 0.0 & 0.0 & 0.3 & 1.2 & 0.0 & 0.0 & 0.0 & 0.1 & 0.0 & 0.1 \\
\hline NCOT & $\begin{array}{l}\text { Nitzschia constricta (Kützing) } \\
\text { Ralfs in Pritchard }\end{array}$ & 0.1 & 0.0 & 0.0 & 0.0 & 0.0 & 0.0 & 0.3 & 0.1 & 0.0 & 0.0 & 0.1 & 0.0 & 0.0 & 0.3 & 0.0 & 0.0 & 0.0 \\
\hline NDEN & $\begin{array}{l}\text { Nitzschia denticula Grunow in } \\
\text { Cleve \& Grunow }\end{array}$ & 0.0 & 0.0 & 0.0 & 0.0 & 0.0 & 0.0 & 0.0 & 0.0 & 0.8 & 0.0 & 0.1 & 0.0 & 0.0 & 0.0 & 0.2 & 0.0 & 0.2 \\
\hline NDIS & Nitzschia dissipata (Kützing) Grunow & 0.3 & 2.5 & 3.3 & 1.7 & 3.8 & 0.4 & 3.4 & 1.1 & 0.3 & 1.2 & 0.4 & 0.1 & 0.9 & 2.3 & 2.4 & 0.3 & 0.2 \\
\hline NFIL & Nitzschia filiformis (W. Smith) Hustedt & 0.0 & 0.2 & 0.1 & 0.4 & 1.0 & 0.7 & 0.3 & 0.7 & 0.0 & 0.0 & 0.4 & 0.0 & 0.4 & 0.2 & 0.0 & 0.3 & 0.0 \\
\hline NIFR & Nitzschia frustulum (Kützing) Grunow & 0.0 & 0.0 & 0.0 & 0.0 & 0.0 & 6.0 & 0.0 & 0.0 & 0.0 & 0.0 & 0.0 & 0.0 & 0.0 & 0.0 & 0.0 & 0.0 & 0.0 \\
\hline NHEU & Nitzschia heufleriana Grunow & 0.0 & 0.0 & 0.0 & 0.0 & 0.0 & 0.0 & 0.1 & 0.0 & 0.0 & 0.0 & 0.0 & 0.0 & 0.0 & 0.0 & 0.0 & 0.0 & 0.0 \\
\hline NINC & Nitzschia inconspicua Grunow & 12.2 & 1.0 & 6.1 & 14.6 & 12.4 & 0.1 & 5.7 & 11.1 & 4.5 & 18.6 & 23.5 & 5.6 & 7.3 & 10.5 & 5.2 & 1.7 & 4.4 \\
\hline NMIC & $\begin{array}{l}\text { Nitzschia microcephala Grunow in } \\
\text { Cleve \& Moller }\end{array}$ & 0.0 & 0.0 & 0.0 & 0.3 & 0.1 & 0.0 & 1.6 & 0.0 & 0.0 & 0.0 & 0.1 & 0.0 & 0.1 & 0.0 & 0.0 & 0.0 & 0.0 \\
\hline NREC & Nitzschia recta Hantzsch in Rabenhorst & 0.0 & 0.1 & 0.2 & 0.0 & 0.1 & 0.2 & 0.0 & 0.2 & 0.1 & 0.0 & 0.1 & 0.0 & 0.0 & 0.0 & 0.0 & 0.3 & 0.0 \\
\hline PLFR & $\begin{array}{l}\text { Planothidium frequentissimum } \\
\text { (Lange-Bertalot) Lange-Bertalot }\end{array}$ & 0.0 & 0.0 & 0.0 & 0.0 & 0.6 & 0.4 & 0.5 & 0.1 & 0.0 & 0.0 & 0.0 & 0.1 & 0.3 & 1.9 & 0.0 & 0.3 & 1.5 \\
\hline PTLA & $\begin{array}{l}\text { Planothidium lanceolatum (Brebisson } \\
\text { ex Kützing) Lange-Bertalot }\end{array}$ & 0.0 & 0.0 & 0.0 & 0.0 & 0.0 & 0.0 & 0.1 & 0.0 & 0.0 & 0.0 & 0.0 & 0.0 & 0.0 & 0.0 & 0.0 & 0.0 & 0.0 \\
\hline PTRO & $\begin{array}{l}\text { Planothidium rostratum (Østrup) } \\
\text { Round \& Bukhtiyarova }\end{array}$ & 0.0 & 0.1 & 0.1 & 0.1 & 0.9 & 0.2 & 0.0 & 0.1 & 0.1 & 0.3 & 0.0 & 0.1 & 0.0 & 0.1 & 0.0 & 0.0 & 0.2 \\
\hline PLEV & Pleurosira laevis (Ehrenberg) Compère & 0.0 & 1.0 & 0.4 & 0.1 & 0.4 & 0.7 & 1.3 & 0.5 & 1.0 & 0.3 & 0.1 & 0.3 & 0.5 & 1.1 & 0.0 & 3.3 & 1.2 \\
\hline PSBR & $\begin{array}{l}\text { Pseudostaurosira brevistriata (Grunow) } \\
\text { D. M. Williams \& Round }\end{array}$ & 0.0 & 0.6 & 0.3 & 0.4 & 0.4 & 0.1 & 0.3 & 0.4 & 0.0 & 0.1 & 0.2 & 0.1 & 0.0 & 0.2 & 0.1 & 0.3 & 0.0 \\
\hline RUNI & Reimeria uniseriata Sala, Guerrero \& Ferrario & 2.4 & 0.4 & 1.2 & 2.3 & 1.5 & 1.3 & 5.3 & 13.5 & 1.1 & 0.3 & 0.1 & 0.8 & 0.1 & 0.1 & 1.7 & 0.2 & 0.2 \\
\hline RABB & $\begin{array}{l}\text { Rhoicosphenia abbreviata (C. Agardh) } \\
\text { Lange-Bertalot }\end{array}$ & 0.3 & 2.5 & 2.1 & 1.2 & 2.4 & 4.4 & 3.0 & 1.8 & 1.9 & 0.7 & 10.4 & 5.4 & 2.0 & 5.8 & 1.8 & 5.8 & 3.3 \\
\hline SCVE & $\begin{array}{l}\text { Staurosira construens var. venter } \\
\text { (Ehrenberg) P.B. Hamilton }\end{array}$ & 0.3 & 0.4 & 0.1 & 2.3 & 0.3 & 0.0 & 0.6 & 0.1 & 0.3 & 0.7 & 0.0 & 0.0 & 0.0 & 0.1 & 0.1 & 0.3 & 0.7 \\
\hline SBRE & $\begin{array}{l}\text { Surirella brebissonii Krammer \& } \\
\text { Lange-Bertalot }\end{array}$ & 0.0 & 0.0 & 0.0 & 0.0 & 0.0 & 0.0 & 0.2 & 0.0 & 0.0 & 0.0 & 0.0 & 0.0 & 0.0 & 0.0 & 0.0 & 0.0 & 0.0 \\
\hline THLA & $\begin{array}{l}\text { Thalassiosira lacustris (Grunow) } \\
\text { Hasle in Hasle \& Fryxell }\end{array}$ & 0.1 & 0.4 & 0.2 & 0.2 & 0.4 & 0.5 & 0.3 & 0.1 & 0.0 & 0.0 & 0.0 & 0.1 & 0.0 & 0.3 & 0.1 & 0.0 & 0.0 \\
\hline UULN & Ulnaria ulna (Nitzsch) Compère & 0.7 & 1.6 & 1.2 & 0.3 & 0.1 & 0.3 & 0.6 & 0.5 & 0.2 & 0.3 & 0.4 & 0.2 & 0.3 & 0.6 & 0.1 & 0.5 & 0.5 \\
\hline
\end{tabular}


Table A2. Diatom community descriptive parameters for over the study period at control (C) and impacted sites. Richness (S), Shannon-Wiener's diversity index $\left(\mathrm{H}^{\prime}\right.$, as $\left.\log _{2}\right)$ and Pielou's evenness index (J').

\begin{tabular}{|c|c|c|c|}
\hline & S & $\mathrm{H}^{\prime}\left(\log _{\mathrm{e}}\right)$ & $J^{\prime}$ \\
\hline \multicolumn{4}{|c|}{ Natural Substrate } \\
\hline \multicolumn{4}{|c|}{ Summer } \\
\hline $\mathrm{C}$ & 34 & 2.58 & 0.73 \\
\hline I1 & 40 & 2.97 & 0.80 \\
\hline I2 & 43 & 3.08 & 0.82 \\
\hline \multicolumn{4}{|c|}{ Autumn } \\
\hline $\mathrm{C}$ & 38 & 2.74 & 0.75 \\
\hline I1 & 47 & 3.10 & 0.81 \\
\hline $\mathrm{I} 2$ & 40 & 3.08 & 0.83 \\
\hline \multicolumn{4}{|c|}{ Winter } \\
\hline $\mathrm{C}$ & 42 & 2.91 & 0.78 \\
\hline I1 & 42 & 2.69 & 0.72 \\
\hline $\mathrm{I} 2$ & 38 & 2.88 & 0.79 \\
\hline \multicolumn{4}{|c|}{ Artificial Substrate } \\
\hline \multicolumn{4}{|c|}{ Summer } \\
\hline $\mathrm{C}$ & 32 & 2.74 & 0.79 \\
\hline I 2 & 37 & 2.67 & 0.74 \\
\hline \multicolumn{4}{|c|}{ Autumn } \\
\hline $\mathrm{C}$ & 31 & 2.55 & 0.74 \\
\hline I1 & 37 & 2.41 & 0.67 \\
\hline $\mathrm{I} 2$ & 43 & 3.17 & 0.84 \\
\hline \multicolumn{4}{|c|}{ Winter } \\
\hline $\mathrm{C}$ & 30 & 2.40 & 0.70 \\
\hline I1 & 31 & 3.07 & 0.89 \\
\hline I2 & 41 & 3.05 & 0.82 \\
\hline
\end{tabular}


Table A3. Similarity percentages analysis (SIMPER) of diatom taxa showing mean dissimilarity between control and impacted sites and percentages of taxa contribution until reach 50\%. (a) Natural substrate; (b) Artificial substrate.

(a)

\begin{tabular}{|c|c|c|c|c|c|c|}
\hline Natural substrate & & & & & & \\
\hline \multicolumn{7}{|l|}{ Average dissimilarity: 42.22} \\
\hline & Control & Impacted & & & & \\
\hline Species & Av.Abund & Av.Abund & Av.Diss & Diss/SD & Contrib\% & Cum.\% \\
\hline Amphora pediculus (Kützing) Grunow & 4.85 & 3.87 & 1.84 & 1.34 & 4.37 & 4.37 \\
\hline Nitzschia inconspicua Grunow & 3.1 & 2.05 & 1.61 & 1.35 & 3.81 & 8.18 \\
\hline Navicula capitatoradiata Germain & 1.93 & 0.98 & 1.43 & 1.28 & 3.39 & 11.57 \\
\hline Reimeria uniseriata Sala, Guerrero \& Ferrario & 1.64 & 1.37 & 1.14 & 1.26 & 2.69 & 14.26 \\
\hline Cocconeis placentula var. trilineata (Peragallo \& Héribaud) Cleve & 0.81 & 1.8 & 1.07 & 1.09 & 2.54 & 16.8 \\
\hline Amphora copulata (Kützing) Schoeman \& Archibald & 2.18 & 2.3 & 1.03 & 1.45 & 2.45 & 19.25 \\
\hline Navicula tripunctata (O. F. Müller) Bory & 0.63 & 1.32 & 0.97 & 1.29 & 2.3 & 21.55 \\
\hline Amphora indistincta Levkov & 1.49 & 2.03 & 0.91 & 1.35 & 2.16 & 23.71 \\
\hline Melosira varians $\mathrm{C}$. Agardh & 1.56 & 1.35 & 0.89 & 1.42 & 2.1 & 25.81 \\
\hline Nitzschia dissipata (Kützing) Grunow & 1.12 & 1.08 & 0.87 & 1.34 & 2.07 & 27.88 \\
\hline Cocconeis placentula var. lineata (Ehrenberg) Van Heurck & 1.63 & 2.25 & 0.87 & 1.44 & 2.06 & 29.94 \\
\hline Navicula antonii Lange-Bertalot & 1.76 & 1.78 & 0.86 & 1.4 & 2.04 & 31.99 \\
\hline Achnanthidium minutissimum (Kützing) Czarnecki & 1.2 & 0.78 & 0.83 & 1.39 & 1.97 & 33.95 \\
\hline Nitzschia palea (Kützing) W. Smith & 1.24 & 0.93 & 0.83 & 1.37 & 1.96 & 35.91 \\
\hline Rhoicosphenia abbreviata (C. Agardh) Lange-Bertalot & 1.03 & 1.43 & 0.82 & 1.33 & 1.94 & 37.85 \\
\hline Gomphonema parvulum (Kützing) Kützing & 1.04 & 0.56 & 0.81 & 1.13 & 1.91 & 39.76 \\
\hline Gomphonema rhombicum M. Schmidt & 0.79 & 1.17 & 0.8 & 1.3 & 1.89 & 41.66 \\
\hline Cocconeis pediculus Ehrenberg & 0.73 & 1.3 & 0.8 & 1.23 & 1.89 & 43.55 \\
\hline Staurosira construens var. venter (Ehrenberg) P. B. Hamilton & 0.86 & 0.26 & 0.71 & 1.35 & 1.69 & 45.24 \\
\hline Pleurosira laevis (Ehrenberg) Compère & 0.33 & 0.76 & 0.7 & 1.8 & 1.66 & 46.9 \\
\hline Cocconeis placentula Ehrenberg var. euglypta (Ehrenberg) Grunow & 1.43 & 1.8 & 0.7 & 1.3 & 1.65 & 48.55 \\
\hline Navicula veneta Kützing & 0.54 & 0.49 & 0.69 & 1.1 & 1.64 & 50.18 \\
\hline
\end{tabular}

(b)

\begin{tabular}{|c|c|c|c|c|c|c|}
\hline Artificial substrate & & & & & & \\
\hline \multicolumn{7}{|l|}{ Average dissimilarity $=39.97$} \\
\hline & Control & Impacted & & & & \\
\hline Species & Av.Abund & Av.Abund & Av.Diss & Diss/SD & Contrib\% & Cum.\% \\
\hline Amphora pediculus (Kützing) Grunow & 4.58 & 2.82 & 2.75 & 1.52 & 6.88 & 6.88 \\
\hline Nitzschia inconspicua Grunow & 2.85 & 2.69 & 1.54 & 1.01 & 3.86 & 10.74 \\
\hline Rhoicosphenia abbreviata (C. Agardh) Lange-Bertalot & 1.36 & 2.16 & 1.27 & 1.32 & 3.17 & 13.91 \\
\hline Nitzschia palea (Kützing) W. Smith & 0.82 & 1.15 & 1.17 & 1.2 & 2.93 & 16.85 \\
\hline Cocconeis placentula var. trilineata (Peragallo \& Héribaud) Cleve & 1.78 & 2.33 & 1.13 & 1.33 & 2.83 & 19.68 \\
\hline Achnanthidium minutissimum (Kützing) Czarnecki & 1.69 & 1.11 & 1.05 & 1.23 & 2.62 & 22.29 \\
\hline Amphora copulata (Kützing) Schoeman \& Archibald & 2.15 & 2.24 & 1.04 & 1.4 & 2.61 & 24.91 \\
\hline Gomphonema rhombicum M. Schmidt & 1.35 & 1.49 & 1 & 1.33 & 2.51 & 27.41 \\
\hline Navicula cryptotenella Lange-Bertalot & 2.12 & 1.7 & 0.99 & 1.29 & 2.48 & 29.89 \\
\hline Amphora ovalis (Kützing) Kützing & 0 & 0.91 & 0.95 & 1.06 & 2.37 & 32.27 \\
\hline Navicula antonii Lange-Bertalot & 1.64 & 1.01 & 0.93 & 1.09 & 2.32 & 34.58 \\
\hline Cocconeis placentula Ehrenberg var. placentula & 2.11 & 1.87 & 0.92 & 1.44 & 2.3 & 36.88 \\
\hline Gomphonema minutum (C. Agardh) C. Agardh & 1.11 & 1.44 & 0.88 & 1.18 & 2.21 & 39.09 \\
\hline Navicula tripunctata (O. F. Müller) Bory & 0.39 & 1.15 & 0.87 & 1.37 & 2.18 & 41.27 \\
\hline Cocconeis placentula var. lineata (Ehrenberg) Van Heurck & 2.75 & 2.57 & 0.83 & 1.3 & 2.07 & 43.34 \\
\hline Nitzschia amphibia Grunow & 1.51 & 1.47 & 0.78 & 1.43 & 1.96 & 45.3 \\
\hline Amphora indistincta Levkov & 1.2 & 0.51 & 0.78 & 1.51 & 1.95 & 47.26 \\
\hline Gomphonema parvulum (Kützing) Kützing & 0.41 & 0.9 & 0.78 & 1.04 & 1.94 & 49.2 \\
\hline Pleurosira laevis (Ehrenberg) Compère & 0.32 & 0.99 & 0.77 & 1.41 & 1.93 & 51.13 \\
\hline
\end{tabular}

